2. To: (Receiving Organization) TWRs Safety \& Licensing

5. Proj./Prog./Dept./Div.:

Interim stabilization

8. Originotor Remarks:

Calculation notes are used to document the originator's analysis but are not to be used as the final or sole document to authorize activities or justify facility modifications.

11. Receiver Remarks: 11A. Desion Baseline Document? [] Yes [ $\mathrm{x}$ ] No
3. From: (originating orgenization) TWRS Safety Analysis

6. Design Authority/ Design Agent/Cog. Engr.:

G. W. Ryan
4. Related EDT Mo.:

$$
\text { N/A }
$$

7. Purchase Order Mo.:

$$
\text { N/A }
$$

9. Equip./Component Mo.:

$$
\mathbf{N} / \mathbf{A}
$$

10. Systera/Bldg./Facility:

\section{1-A-101/Tank Farms}

12. Mejor Assm. Dwg. Mo.:

N/A

13. Permit/Permit Application Mo.: N/A

14. Required Response Date:

May 6, 1997

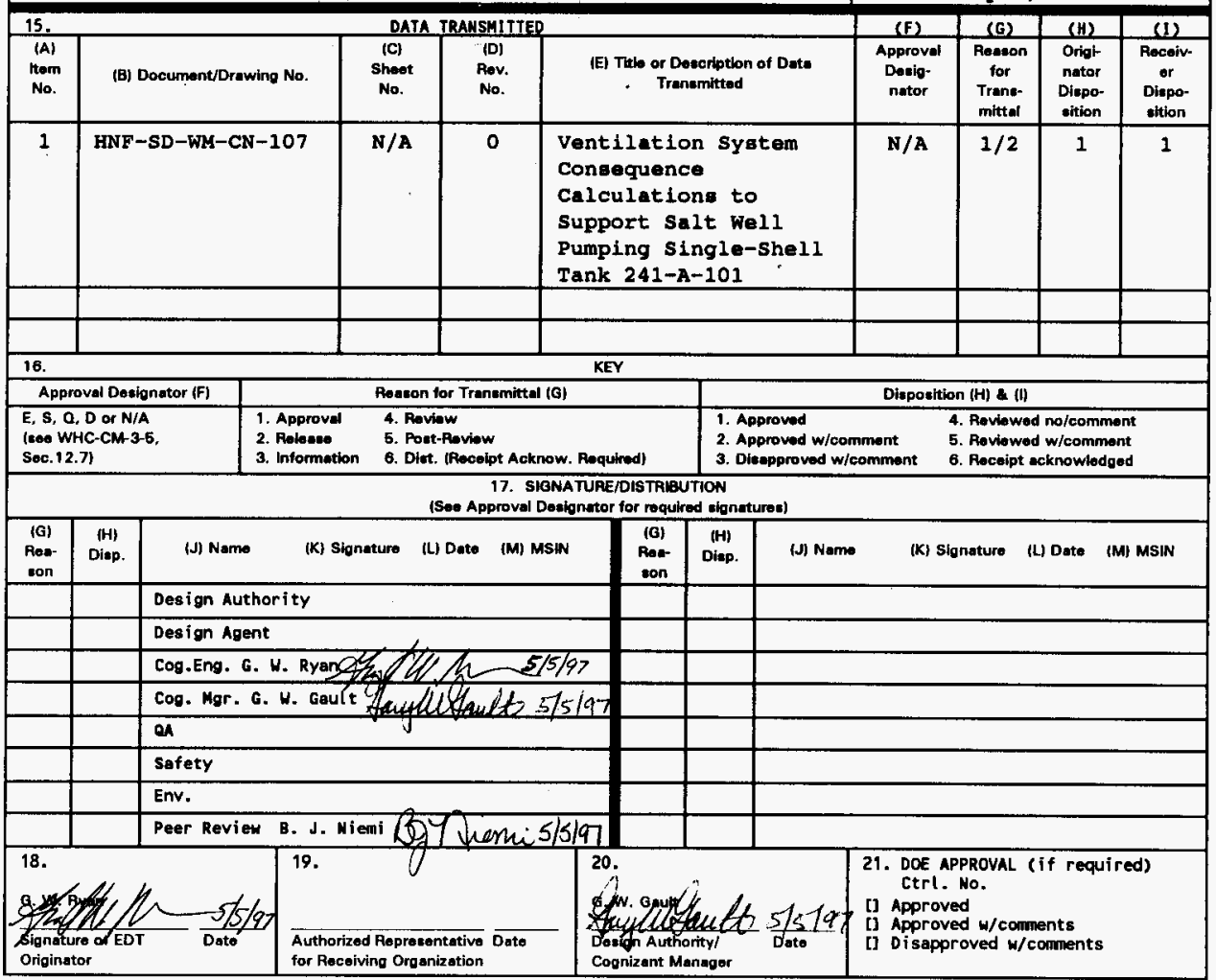

BD-7400-172-2 (05/96) GEF097 


\section{Ventilation System Consequence Calculations to Support Salt Well Pumping Single-Shell Tank 241-A-101.}

Grant W. Ryan

DE\&S Hanford, Inc., Richland, WA 99352

U.S. Department of Energy Contract DE-AC06-87RL10930

EDT/ECN: 621228

Org Code: 2N170

B\&R Code: EW3120071
UC: 510

Charge Code: E60181

Total Pages: 61

Key Words: 241-A-101, contaminated fire, fire, HEPA filter fire, radioactive materials, salt we 11 pumping, TWRS, tank farms, ventilation system.

Abstract: This document presents the radiological dose and toxicological exposure calculations for an accident scenario involved with the ventilation system used to support salt well pumping single-shell tank 241-A-101.

TRADEMARK OISCLAIMER. Reference herein to any specific connercial procuct, process, or service by trade name, trademark, manufacturer, or otherwise, does not necessarily constitute or imply its endorsement, recommendation, or favoring by the United states Government or any agency thereof or its contractors or subcontractors.

Printed in the United States of Americo. To obtain copies of this document, contact: WHC/BCS Document Control Services, P.O. Box 1970, Mailstop H6-08, Richland wa 99352, Phone (509) 372-2420; Fax (509) 376-4989.
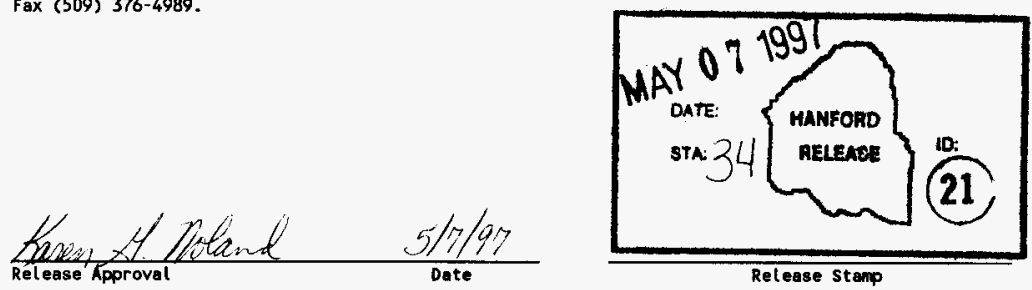

Release Stanp 
VENTILATION SYSTEM CONSEQUENCE CALCULATIONS TO SUPPORT SALT WELL PUMPING SINGLE-SHELL TANK 241-A-101

\section{REVISION 0}

TWRS Safety Analysis

SPECIAL NOTE REGAROING PROCEDURE COMPLIANCE:

This calculation note has been developed in accordance with the requirements defined in procedure WP-6.7, Revision 1, of WHC-CM-6-32, Safety Analysis and Nuclear Engineering Work Procedures and has been technically peer reviewed in accordance with the requirements defined in procedure WP-6.2, Revision 1, of WHC-CM-6-32.

May 1997

1 of 60 
HNF-SD-WM-CN-107 REV 0

This page intentionally left blank. 


\section{CONTENTS}

1.0 INTRODUCTION AND PURPOSE ................. . 7 of 60

2.0 ANALYSIS INPUT ............................ 11 of 60

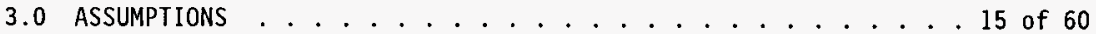

4.0 ANALYTICAL METHODS AND CALCULATIONS ........... . 17 of 60

5.0 RADIOLOGICAL DOSE CONSEQUENCE ANALYSIS . . . . . . . . . 19 of 60

6.0 TOXICOLOGICAL EXPOSURE CONSEQUENCE ANALYSIS . . . . . . . 27 of 60

7.0 ANALYSIS RESULTS .......................... 31 of 60

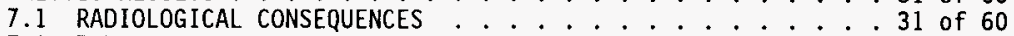

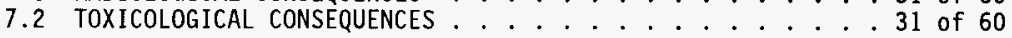

8.0 CONCLUSIONS .................................. of 60

9.0 REFERENCES ..................... . . 37 of 60

\section{APPENDICES}

A DEVELOPMENT AND DISCUSSION OF HEPA FILTER RELEASE AMOUNTS . . . 39 of 60

B BACKGROUND INFORMATION ......................... 45 of 60

C DETAILED CONSEqUENCE ANALYSIS RESULTS . . . . . . . . 49 of 60

D PEER REVIEW AND HEDOP REVIEW CHECKLISTS . . . . . . . . . 57 of 60 
1. Input Data Used to Develop the Consequence Analyses . . . . . . 11 of 60

2. Unit Liter Doses for Tank Waste Composites . . . . . . . . . 11 of 60

3. Summary of Onsite $X / Q^{\prime}$ Values............... 12 of 60

4. Summary of offsite $x / Q^{\prime}$ Values .............. 13 of 60

5. Particulate Release Rates. .. . . . . . . . . . . . . . . 13 of 60

6. Summary of Onsite Radiological Consequences

Assuming No Controls ................. . . 32 of 60

7. Summary of Offsite Radiological Consequences Assuming No Controls ................ 32 of 60

8. Summary of Onsite Toxicological Consequences Assuming No Controls ................ . . 33 of 60

9. Summary of Offsite Toxicological Consequences

Assuming No Controls ................. . 33 of 60

10. Summary of Technical Safety Requirements. . . . . . . . . 35 of 60 


\section{LIST OF TERMS}

$\begin{array}{ll}\text { ARF } & \text { airborne release fraction } \\ \text { BIO } & \text { basis for interim operation } \\ \text { CEDE } & \text { committed effective dose equivalent } \\ \text { DOE } & \text { U. S. Department of Energy } \\ \text { FDH } & \text { Fluor Daniel Hanford } \\ \text { FSAR } & \text { final safety analysis report } \\ \text { HEDOP } & \text { Hanford Environmental Dose Overview Panel } \\ \text { rem } & \text { radiation effective man } \\ \text { RF } & \text { respirable fraction } \\ \text { SST } & \text { single-shell tank } \\ \text { SV } & \text { sievert } \\ \text { TEDE } & \text { total effective dose equivalent } \\ \text { TWRS } & \text { Tank Waste Remediation System } \\ \text { ULD } & \text { unit liter dose } \\ \text { WHC } & \text { Westinghouse Hanford Company }\end{array}$


HNF-SD-WM-CN-107 REV 0

This page intentionally left blank.

6 of 60 


\section{VENTILATION SYSTEM CONSEQUENCE CALCULATIONS TO SUPPORT SALT WELL PUMPING SINGLE-SHELL TANK 241-A-101}

\subsection{INTRODUCTION AND PURPOSE}

The purpose of this document is to evaluate the potential radiological dose and toxicological exposure consequences associated with the portable ventilation system used for salt well pumping single-shell tank 241-A-101. The calculations and assumptions used in this document are, in many cases, similar or identical to those used in calculation note WHC-SD-WM-CN-062, HEPA Filter Failure by Fire or Heater Overtemperature and Subsequent Unfiltered Release. Some requested refinements in this analysis are the use of the maximum design flowrate of the exhaust fan used to ventilate 241-A-101 (i.e., $0.236 \mathrm{~m}^{3} / \mathrm{s}$ [500 $\left.\mathrm{cfm}\right]$ ) and alternate radiological dose calculations to show the results of using a 241-A-101 tank-specific source term as defined in WHC-SD-WM-SAD-036, A Safety Assessment for Salt Well Jet Pumping operations in Tank 241-A-101: Hanford Site, Rich7and, Washington.

WHC-SD-WM-CN-062 was developed to support the accident scenario, HEPA Filter Failure - Exposure to High Temperature or Pressure, presented in the TWRS Basis for Interim Operation (BI0) and the Final Safety Analysis Report (FSAR). The results of the consequence analysis documented in WHC-SD-WM-CN-062 demonstrated the need for safety-significant Ventilation Stack Continuous Air Monitor (CAM) Interlock Systems on actively ventilated single-shell and double-shell waste tanks. The safety functions of the ventilation stack CAM interlock systems are to limit an unfiltered release of ventilation exhaust to the atmosphere to a period of ten minutes or less, thus reducing the consequences of the HEPA Filter Failure - Exposure to High Temperature or Pressure accident.

Instead of accepting and implementing this safety SSC for use in the operation of the ventilation system used to support salt well pumping 241-A-101, salt well pumping project management has expressed an interest in exploring alternate control options for this ventilation system. The results of the analysis performed in this document will help to provide the basis for any safety SSCs or controls that may need to be developed specifically for the operation of this exhauster. Note that the development and documentation of any safety SSCS or controls that are necessary to control the operation of this specific exhauster will occur outside of this calculation note.

In this document, the terms ventilation system and exhauster are used interchangeably.

\section{ACCIDENT SCENARIO DESCRIPTION}

The same accident scenario that is analyzed in WHC-SD-WM-CN-062 is evaluated in this document. The scenario assumes that a fire occurs in or around the ventilation system and the heat from the fire degrades the filters. Degradation of the filters is assumed to result in the release of a fraction of the inventory of tank waste accumulated on the prefilter, the two in-series HEPA filters, and a fraction of the inventory of tank waste that has accumulated in the ventilation system ductwork. The fire ultimately results in an unfiltered release pathway to the environment. Subsequent to the fire, 
the exhaust fan continues to operate, exhausting the headspace constituents of the waste tank to the atmosphere.

It should be noted that the authorization basis documentation (i.e., WHC-SD-WM-SAD-036) for salt well pumping 241-A-101 did not identify or analyze this accident scenario. It is being analyzed here to demonstrate consistency with the TWRS BIO and to be sure that any additional, necessary controls are identified.

The scenario analyzed bounds the hazard associated with an unfiltered release due to seal failure, a defective or deteriorated HEPA filter, or improper installation of HEPA filter. The fire scenario is selected for analysis as its consequences are bounding due to the additional release associated with the filter inventory.

The total consequences of this event are calculated by (1) adding the consequences due to the amount of respirable material released during the HEPA filter failure and (2) the amount of respirable material released during the subsequent continuous, unfiltered release following the filter failure.

The material at risk on the pre-filter and HEPAs is assumed to have a contact dose rate of less than or equal to $200 \mathrm{mrem} / \mathrm{h}(2.0 \mathrm{E}-03 \mathrm{~Sv} / \mathrm{h})$. Since this is an assumption for filter loading it requires protection via a technical safety requirement (TSR) level control (see Section 8.0). The contact dose rate is based on operational history and bounds the contact dose rates observed in the tank farms. WHC-SD-WM-CN-033, Microshield ${ }^{\star}$ Dose Rate Calculations for HEPA Filters and Prefilters, uses the contact dose rate to back calculate the inventory on the filters.

Consequences resulting from the unfiltered release pathway are calculated for 12 hours (onsite receptor only), 24 hours (offsite receptor only), and for durations of 1 week, 3 months, 6 months, and one year for both the onsite and offsite receptors. For unfiltered release durations greater than one week, the dose to the onsite receptor is adjusted by an occupancy factor of 0.286 to account for the actual time spent at work. The occupancy factor only applies to the onsite receptor (WHC-SD-WM-SARR-016). It is assumed that the exhaust fan continues to run at the maximum design ventilation flowrate of $0.236 \mathrm{~m}^{3} / \mathrm{s}(500 \mathrm{cfm})$.

The consequences created as a result of the $1 \mathrm{yr}$ (or annual) unfiltered release are calculated because the ventilation system operates continuousiy such that the release duration is essentially infinite in the absence of controls. This is in contrast to other potential accidents that have a finite duration. The consequences as a result of the annual unfiltered release show the sensitivity of the analysis to assumptions regarding release duration and can be used in conjunction with the various accident duration consequences to select the necessary and sufficient set of controls.

\section{ACCIDENT FREQUENCY DEVELOPMENT}

The event frequency for this accident scenario assuming no controls is qualitatively assessed to be anticipated $\left(>10^{-2}\right.$ to $\left.\leq 10^{\circ}\right)$ based on the initiating event frequency for an external fire. An external fire around the ventilation system would likely cause a filter degradation, as analyzed here, and is consistent with the analysis presented in Section 5.3.2.3 of the TWRS 


\section{HNF-SD-WM-CN-107 REV 0}

BIO and the accompanying calculation note, WHC-SD-WM-CN-056, Fire in a Contaminated Area, that evaluates the consequences of a fire in a contaminated area.

The consequences associated with this accident scenario are compared to the risk acceptance guidelines for anticipated accidents as provided in WHC-CM-4-46, Rev. 1 . 
HNF-SD-WM-CN-107 REV O

This page intentionally left blank. 


\subsection{ANALYSIS INPUT}

The input data shown in Table 1 is used in this document to develop the radiological and toxicological consequence analyses for the 241-A-101 Exhauster.

Table 1. Input Data Used to Develop the Consequence Analyses.

\begin{tabular}{|l|l|}
\hline \multicolumn{1}{|c|}{ Parameter } & \multicolumn{1}{|c|}{ Value } \\
\hline Facility/Vent System & $241-\mathrm{A}-101$ Exhauster \\
\hline $\begin{array}{l}\text { HEPA Filter Dimensions and Vent System } \\
\text { Configuration }\end{array}$ & $24 " \times 24^{\prime \prime} \times 5-7 / 8{ }^{\prime \prime}$ \\
\hline Maximum Design Flowrate of Vent System & $0.236 \mathrm{~m}^{3} / \mathrm{s} \mathrm{(500} \mathrm{cfm)}$ \\
\hline Type of Waste Released From the Vent System & SST Solids \\
\hline Amount Released & $3.06 \mathrm{E}-05 \mathrm{~L}^{\mathrm{b}}$ \\
\hline
\end{tabular}

aThese are the HEPA filter dimensions as Listed on Hanford design drawing H-14-100737, sheet 10 . The amount released from the ventilation system configuration consists of the amount from two HEPAs, a prefilter, and another volume equal to the prefilter for material coning out of the ventilation ducting: 2 HEPA Volumes +2 Prefilter volumes. Information gathered in relation to this exhauster is included in Appendix $B$ of this document.

bThe amount released is taken from information presented in Appendix $A$ of this document for SSTs with active vent ilation. The information presented in Appendix A Was specifically developed for use in WHC-SD-WM-CN-062, HEPA Filter Failure by Fire or Heater Overtemperature and Subsequent Unfiltered Release, and is now being utilized in this calculation note. To most accurately represent the exhauster being used for 241-A-101, the value shown only reflects the volume released from one filter bank. This is a conservative value since there is a slight difference in the dimensions of the filter size evaluated ( $24^{\prime \prime} \times 24^{\prime \prime} \times 12^{\prime \prime}$ ) in $\mathrm{CN}-062$ and those used in this exhauster.

Additionally, to supplement the information in Table 1 , the unit liter doses (ULDs) for the bounding (from WHC-SD-WM-SARR-016) and tank-specific source terms (from WHC-SD-WM-SAD-036, last column, Table H-2, page H-4) utilized in this analysis are included in Table 2.

Table 2. Unit Liter Doses for Tank Waste Composites.

\begin{tabular}{|l|c|c|}
\hline \multicolumn{1}{|c|}{ Composite } & $\begin{array}{c}\text { Inhalation ULD } \\
(\text { Sv } / L)\end{array}$ & $\begin{array}{c}\text { Ingestion ULD* } \\
\left(\text { Sv }-\mathrm{m}^{3} / \mathrm{s}-\mathrm{L}\right)\end{array}$ \\
\hline $\begin{array}{l}\text { SST Solids (bounding value from } \\
\text { WHC-SD-WM-SARR-016) }\end{array}$ & $2.2 \mathrm{E}+05$ & 4.1 \\
\hline $\begin{array}{l}\text { SST Solids (tank-specific value from } \\
\text { WHC-SD-WM-SAD-036) }\end{array}$ & $7.39 \mathrm{E}+04$ & $\mathrm{~N} / \mathrm{A}$ \\
\hline
\end{tabular}

*Includes 24 hours ingestion of fruits and vegetables, ground shine, inadvertent soil ingestion, and inhalation of material resuspended from the ground. This value has only been documented for the bounding source term value.

ULD = unit $t i$ ter dose. 


\section{DISPERSION COEFFICIENTS}

The following dispersion coefficients are developed for use in this accident analysis:

\section{Onsite:}

The $X / Q^{\prime}$ for the acute release from the HEPA filter is $3.41 \times 10^{-2} \mathrm{~s} / \mathrm{m}^{3}$ (Table 4, WHC-SD-WM-SARR-016).

To determine the $x / Q^{\prime}$ for the 12 hour release, the logarithmic interpolation procedure described in WHC-SD-WM-SARR-016 is used to correctly identify the proper $x / Q$ 's to be used. The $X / Q^{\prime}$ used for the 2 hour release is $1.13 \times 10^{-2} \mathrm{~s} / \mathrm{m}^{3}$ to account for plume meander (Table 4, WHC-SD-WM-SARR-016). Using the equation from WHC-SD-WM-SARR-016 yields:

$$
\frac{\log \left(1.13 \times 10^{-2}\right)-\log \left(\times / 0^{\prime} 12 \mathrm{hr}\right)}{\log \left(1.13 \times 10^{-2}\right)-\log \left(4.03 \times 10^{-4}\right)}=\frac{\log (2 \mathrm{hr})-\log (12 \mathrm{hr})}{\log (2 \mathrm{hr})-\log (8,760 \mathrm{hr})}
$$

The onsite $x / Q^{\prime}(12 \mathrm{hr})$ is $5.54 \times 10^{-3} \mathrm{~s} / \mathrm{m}^{3}$.

The $x / Q$ 's for the 1 week, 3 month, and 6 month releases are also calculated using the logarithmic interpolation procedure. These values, along with the $x / Q^{\prime} s$ calculated above, are summarized in Table 3 .

Table 3. Summary of Onsite $x / Q^{\prime}$ Values

\begin{tabular}{|l|c|l|}
\hline \multicolumn{1}{|c|}{ Duration } & $X / Q^{\prime}$ value $\left(\mathrm{s} / \mathrm{m}^{3}\right)$ & \multicolumn{1}{|c|}{ Source } \\
\hline Acute Release $(<\mathrm{hr})$ & $3.41 \mathrm{E}-02$ & Table 4, WHC-SD-WM-SARR-016 \\
\hline $12 \mathrm{hr}$ & $5.54 \mathrm{E}-03$ & Logarithmic interpolation \\
\hline $168.5 \mathrm{hr}(1 \mathrm{week})$ & $1.94 \mathrm{E}-03$ & Logarithmic interpolation \\
\hline $730 \mathrm{hrs}$ (1 month) & $1.08 \mathrm{E}-03$ & Logarithmic interpolation \\
\hline $2,190 \mathrm{hrs}(3$ months) & $6.99 \mathrm{E}-04$ & Logarithmic interpolation \\
\hline $4,380 \mathrm{hrs}(6$ months) & $5.31 \mathrm{E}-04$ & Logarithmic interpolation \\
\hline $8,760 \mathrm{hrs}(1 \mathrm{yr})$ & $4.03 \mathrm{E}-04$ & Table 9, WHC-SD-WM-SARR-016 \\
\hline
\end{tabular}

\section{Offsite:}

The $X / Q^{\prime}$ for the acute release from the $H E P A$ filter is $2.83 \times 10^{-5} \mathrm{~s} / \mathrm{m}^{3}$ (Table 5, WHC-SD-WM-SARR-016). 
To determine the $X / Q^{\prime}$ for the 24 hour release, the logarithmic interpolation procedure described in WHC-SD-WM-SARR-016 is used to correctly identify the proper $x / Q^{\prime} s$ to be used. The $X / Q^{\prime}$ used for the 2 hour release is $2.12 \times 10^{-5} \mathrm{~s} / \mathrm{m}^{3}$ to account for plume meander (Table 5, WHC-SD-WM-SARR-016). Using the equation from WHC-SD-WM-SARR-016 yields:

$$
\frac{\log \left(2.12 \times 10^{-5}\right)-\log \left(x / Q^{1} 24 \mathrm{hr}\right)}{\log \left(2.12 \times 10^{-5}\right)-\log \left(1.24 \times 10^{-7}\right)}=\frac{\log (2 \mathrm{hr})-\log (24 \mathrm{hr})}{\log (2 \mathrm{hr})-\log (8,760 \mathrm{hr})}
$$

The offsite $X / Q^{\prime}(24 \mathrm{hr})$ is $4.62 \mathrm{E}-06 \mathrm{~s} / \mathrm{m}^{3}$.

The $x / Q$ 's for the 1 week, 3 month, and 6 month releases are also calculated using the logarithmic interpolation procedure. These values, along with the $X / Q$ 's calculated above, are summarized in Table 4.

Table 4. Summary of offsite $x / Q^{\prime}$ Values

\begin{tabular}{|l|c|l|}
\hline \multicolumn{1}{|c|}{ Duration } & $x / Q^{\prime}$ value $\left(\mathrm{s} / \mathrm{m}^{3}\right)$ & \multicolumn{1}{c|}{ Source } \\
\hline Acute Release (<1 hr) & $2.83 \mathrm{E}-05$ & Table 5, WHC-SD-WM-SARR-016 \\
\hline $24 \mathrm{hr}$ & $4.62 \mathrm{E}-06$ & Logarithmic interpolation \\
\hline $168.5 \mathrm{hr}(1$ week) & $1.40 \mathrm{E}-06$ & Logarithmic interpolation \\
\hline $730 \mathrm{hrs}(1$ month) & $5.69 \mathrm{E}-07$ & Logarithmic interpolation \\
\hline $2,190 \mathrm{hrs}(3$ months) & $2.90 \mathrm{E}-07$ & Logarithmic interpolation \\
\hline $4,380 \mathrm{hrs}(6$ months) & $1.90 \mathrm{E}-07$ & Logarithmic interpolation \\
\hline $8,760 \mathrm{hrs}(1 \mathrm{yr})$ & $1.24 \mathrm{E}-07$ & Table 9, WHC-SD-WM-SARR-016 \\
\hline
\end{tabular}

For the unfiltered release following the failure of the HEPA filters, Table 5 presents the particulate release rate from the headspace of tank 241-A-101.

Table 5. Particulate Release Rates.

\begin{tabular}{|c|c|c|c|c|}
\hline \multirow{2}{*}{$\begin{array}{c}\text { Facility/vent } \\
\text { system }\end{array}$} & \multicolumn{2}{|c|}{ Flow rate ${ }^{a}$} & \multirow{2}{*}{$\begin{array}{l}\text { Partition } \\
\text { Fraction } \\
\text { Applied }\end{array}$} & \multirow{2}{*}{$\begin{array}{c}\text { Particulate } \\
\text { Release } \\
\text { Rate }^{\mathrm{a}}(\mathrm{L} / \mathrm{s})\end{array}$} \\
\hline & $\left(\mathrm{m}^{3} / \mathrm{s}\right)$ & $(L / s)$ & & \\
\hline 241-A-101 Exhauster & 0.236 & 236 & $1.0 E-10$ & $2.4 E-08$ \\
\hline
\end{tabular}

athe particulate release rate $(L / S)$ is calculated by multiplying the ventilation flaw rate $(L / S)$ by the partition fraction. 
HNF-SD-WM-CN-107 REV 0

This page intentionally left blank. 


\subsection{ASSUMPTIONS}

The following assumptions were used in this analysis (in no particular order):

- The dose rate "on contact" from pre-filters and HEPA filters is $\leq 200 \mathrm{mR} / \mathrm{hr}$. According to the approved Information Validation Form (IVF) provided in Appendix B of WHC-SD-WM-CN-062, HEPA Filter Failure by Fire or Heater Overtemperature and Subsequent Unfiltered Release, Tank Farm Operations personnel confirm that HEPA fi]ters are changed when the contact dose rate is less than $200 \mathrm{mR} / \mathrm{hr}$ (i.e., $160 \mathrm{mR} / \mathrm{hr}$ ). The location for calculating the contact dose rate on pre-filters and HEPA filters is defined in WHC-SO-WM-CN-033.

- A11 HEPA filters are assumed to be compromised and release a fraction of their contents during a fire in or around the ventilation system.

- The filter media making up the HEPA filters is made of fiberglass (or other non-combustible material). There is no paper (or other highly combustible) filter media used in the Tank Farm ventilation systems HEPA filters.

- The ventilation system remains in operation (i.e., fan running) during and following the fire (or overtemperature) event that fails the HEPA filters.

- An additional amount of contamination equal to the loading on the pre-filter is used in order to account for accumulation in the ventilation duct work.

- The type of waste material that is released from both the ventilation system (filters and ductwork) and the tank headspace is SST Solids with a bounding ULD of $2.2 \times 10^{5} \mathrm{~Sv} / \mathrm{L}$ (see Table 2). This source term bounds the SST Liquids waste type that has an inhalation ULD of $1.1 \times 10^{4} \mathrm{SV} / \mathrm{L}$.

- The respirable fraction (RF) for the unfiltered release is assumed to be 1.0 in all cases.

- The unfiltered release amount, based on the maximum design ventilation system flowrate shown in Table 1 , is calculated utilizing a partition fraction to determine the amount of contamination in the headspace air. A partition fraction of $1.0 \times 10^{-10}$ is used for 241-A-101. The partition fraction cited here is based on experimental results published in RHO-RE-SA-216, Characterization of Airborne Radionuclide Particulates in Ventilated Liquid Waste Tanks for agitated $\left(1.0 \times 10^{-8}\right)$ and unagitated $\left(1.0 \times 10^{-10}\right)$ tanks under both active and passive ventilation. The use of the lower partition fraction is considered reasonable and conservative since the salt well pumping activity is not expected to agitate the waste inside single-shell tank 241-A-101.

- The airborne release fraction (ARF) used to determine the amount of respirable material released from the HEPA filters as a result of exposure to high temperature or fire is $1.0 \times 10^{-4}$. This bounding value, for fiberglass filters, is based on information presented in Section 5.4.1 of DOE-HDBK-3010-94, Airborne Release Fractions/Rates and Respirable Fractions for Nonreactor Nuclear Facilities, for HEPA filters 
subjected to thermal stress. This value is considered applicable and conservative for use in this analysis since the filters used in tank farm ventilation systems are fiberglass and similar to those empirically evaluated in DOE-HDBK-3010-94. The value for the HEPA filter release amount (including prefilter and ductwork accumulation) is summarized in Table 1. The release amount shown in Table 1 is developed in the discussion and worksheets of Appendix $A$.

- The typical acute breathing rate $\left(3.3 \times 10^{-4} \mathrm{~m}^{3} / \mathrm{s}\right)$ is used to calculate the onsite receptor dose for all release durations up to one week. The chronic breathing rate $\left(2.7 \times 10^{-4} \mathrm{~m}^{3} / \mathrm{s}\right)$ is used for onsite receptor dose calculations with release durations greater than one week (WHC-SD-WM-SARR-016, page 4-4).

For the calculation of the offsite receptor dose, the typical acute breathing rate $\left(3.3 \times 10^{-4} \mathrm{~m}^{3} / \mathrm{s}\right)$ is used for all release durations less than one day $(24 \mathrm{hr})$. For release durations greater than or equal to one day $(24 \mathrm{hr})$, the typical chronic breathing rate $\left(2.7 \times 10^{-4} \mathrm{~m}^{3} / \mathrm{s}\right)$ is used to calculate the offsite receptor dose (WHC-SD-WM-SARR-016, page 4-4).

- For unfiltered release durations greater than one week, the dose to the onsite receptor is adjusted by an occupancy factor of 0.286 to account for the actual time spent at work. The occupancy factor only applies to the onsite receptor (WHC-SD-WM-SARR-016, page 4-4). 


\subsection{ANALYTICAL METHODS AND CALCULATIONS}

The total consequences of this event are calculated by adding the consequences due to the amount of respirable material released during the HEPA filter failure and the amount of respirable material released during the subsequent continuous, unfiltered release following the filter failure.

Consequences resulting from the unfiltered release pathway are calculated for 12 hours (onsite receptor only), 24 hours (offsite receptor only), and for durations of 1 week, 3 months, 6 months, and one year for both the onsite and offsite receptors. For unfiltered release durations greater than one week, the dose to the onsite receptor is adjusted by an occupancy factor of 0.286 to account for the actual time spent at work. The occupancy factor only applies to the onsite receptor (WHC-SD-WM-SARR-016). It is assumed that the exhaust fan continues to run at the maximum design ventilation flowrate of $0.236 \mathrm{~m}^{3} / \mathrm{s}(500 \mathrm{cfm})$.

Overall, the methodology used to calculate the radiological and toxicological consequences is presented and discussed in WHC-SD-WM-SARR-016 and WHC-SD-WM-SARR-011, respectively. 
HNF-SD-WM-CN-107 REV 0

This page intentionally left blank.

18 of 60 


\subsection{RADIOLOGICAL DOSE CONSEQUENCE ANALYSIS}

Given an airborne source term, the doses from the inhalation and ingestion pathways are calculated by the following formulas:

Inhalation:

$$
D_{\mathrm{inh}}(S V)=Q(L) \times \frac{X}{Q^{4}}\left(\frac{s}{m^{3}}\right) \times R\left(\frac{m^{3}}{s}\right) \times U L D_{\mathrm{inh}}\left(\frac{S V}{L}\right)
$$

Ingestion:

$$
D_{\text {ing }}(S v)=Q(L) \times \frac{X}{Q^{\prime}}\left(\frac{s}{m^{3}}\right) \times U L D_{\text {ing }}\left(\frac{s v-m^{3}}{s-L}\right)
$$

where

$$
\begin{aligned}
& \mathrm{D}_{\mathrm{inh}}=\text { dose due to inhalation (Sv) } \\
& D_{\text {ing }}=\text { dose due to ingestion (Sv) } \\
& Q=\text { respirable source term (L) } \\
& X / Q^{\prime}=\text { appropriate atmospheric dispersion coefficient }\left(\mathrm{s} / \mathrm{m}^{3}\right) \\
& R=\text { breathing rate (for values, see assumptions in Section } 3.0 \text { ) } \\
& U L D_{i n h}=\text { inhalation unit liter dose }(S V / L \text {, see Table 2) } \\
& U L D_{\text {ing }}=\text { ingestion unit liter dose }\left(S v-m^{3} / s-L \text {, see Table } 2\right) \text {. }
\end{aligned}
$$
offsite individual. 


\section{ONSITE RADIOLOGICAL CONSEQUENCES}

Consequences from the HEPA Filter Failure $\left(D_{f i l t e r}\right)$ :

$$
D_{\mathrm{inh}}(S v)=Q(L) \times \frac{X}{Q^{\prime}}\left(\frac{s}{m^{3}}\right) \times R\left(\frac{m^{3}}{s}\right) \times U L D_{\mathrm{inh}}\left(\frac{S V}{L}\right)
$$

where

$$
\begin{aligned}
& D_{i n h}=\text { dose due to inhalation (Sv) } \\
& Q=3.06 \times 10^{-5} \mathrm{~L} \text { (see Table 1) } \\
& X / Q^{\prime}\left.=3.41 \times 10^{-2} \mathrm{~s} / \mathrm{m}^{3} \text { (see Section } 2.0\right) \\
& R\left.=3.3 \times 10^{-4} \mathrm{~m}^{3} / \mathrm{s} \text { (see Section } 3.0\right) \\
& U L D_{\text {inh }}=2.2 \times 10^{5} \mathrm{SV} / \mathrm{L}(\text { see Table } 2) \\
& D_{\text {filter }}=\left(3.06 \times 10^{-5} \mathrm{~L}\right)\left(3.41 \times 10^{-2} \mathrm{~s} / \mathrm{m}^{3}\right)\left(3.3 \times 10^{-4} \mathrm{~m}^{3} / \mathrm{s}\right)\left(2.2 \times 10^{5} \mathrm{~Sv} / \mathrm{L}\right) \\
& D_{\text {filter }}=7.58 \times 10^{-5} \mathrm{~Sv}
\end{aligned}
$$

Consequences from the 12 hour Unfiltered Release $\left(D_{12}\right.$ hour $)$ :

$$
D_{\mathrm{inh}}(S V)=Q(L / s) \times \frac{X}{Q^{1}}\left(\frac{s}{m^{3}}\right) \times R\left(\frac{m^{3}}{s}\right) \times U L D_{\mathrm{inh}}\left(\frac{s V}{L}\right) \times t(s)
$$

where

$$
\begin{aligned}
& D_{\text {inh }}=\text { dose due to inhalation (Sv) } \\
& Q=2.4 \times 10^{-8} \mathrm{~L} / \mathrm{s} \text { (see Table 5) } \\
& X / Q^{\prime}=5.54 \times 10^{-3} \mathrm{~s} / \mathrm{m}^{3} \text { (see Section 2.0) } \\
& R=3.3 \times 10^{-4} \mathrm{~m}^{3} / \mathrm{s} \text { (see Section } 3.0 \text { ) } \\
& U L D_{i n h}=2.2 \times 10^{5} \mathrm{~Sv} / \mathrm{L} \text { (see Table 2) } \\
& \mathrm{t}=43,200 \mathrm{~s}(12 \mathrm{~h}) \\
& D_{12 \text { hour }}=\left(2.4 \times 10^{-8} \mathrm{~L} / \mathrm{s}\right)\left(5.54 \times 10^{-3} \mathrm{~s} / \mathrm{m}^{3}\right)\left(3.3 \times 10^{-4} \mathrm{~m}^{3} / \mathrm{s}\right) \times \\
& \left(2.2 \times 10^{5} \mathrm{SV} / \mathrm{L}\right)(43,200 \mathrm{~s}) \\
& D_{12 \text { hour }}=4.17 \times 10^{-4} \mathrm{~Sv} \\
& 20 \text { of } 60
\end{aligned}
$$


Consequences from an Annual $(8,760 \mathrm{~h})$ Unfiltered Release $\left(D_{\text {annual }}\right)$ :

$$
\mathrm{D}_{\mathrm{inh}}(S V)=Q(L / s) \times \frac{X}{Q^{1}}\left(\frac{s}{m^{3}}\right) \times R\left(\frac{m^{3}}{s}\right) \times U L D_{\mathrm{inh}}\left(\frac{S V}{L}\right) \times t(s) \times O F
$$

where

$$
\begin{aligned}
& D_{\text {inh }}=\text { dose due to inhalation (Sv) } \\
& Q=2.4 \times 10^{-8} \mathrm{~L} / \mathrm{s} \text { (see Table 5) } \\
& x / Q^{\prime}=4.03 \times 10^{-4} \mathrm{~s} / \mathrm{m}^{3} \text { (see Section 2.0) } \\
& R=2.7 \times 10^{-4} \mathrm{~m}^{3} / \mathrm{s} \text { (see Section } 3.0 \text { ) } \\
& U L D_{i n h}=2.2 \times 10^{5} \mathrm{~Sv} / \mathrm{L} \text { (see Table 2) } \\
& t=3.1536 \times 10^{7} \mathrm{~s}(8,760 \mathrm{~h}) \text { [additional significant figures } \\
& \text { included to reduce error in final answer] } \\
& O F=0.286 \text { (see Section 3.0) } \\
& D_{\text {annual }}=\left(2.4 \times 10^{-8} \mathrm{~L} / \mathrm{s}\right)\left(4.03 \times 10^{-4} \mathrm{~s} / \mathrm{m}^{3}\right)\left(2.7 \times 10^{-4} \mathrm{~m}^{3} / \mathrm{s}\right)\left(2.2 \times 10^{5} \mathrm{~Sv} / \mathrm{L}\right) \times \\
& \left(3.1536 \times 10^{7} s\right)(0.286) \\
& \mathrm{D}_{\text {annual }}=5.18 \times 10^{-3} \mathrm{~Sv}
\end{aligned}
$$

Total onsite consequences (12 hour release):

$$
\begin{gathered}
D_{\text {onsite }(12 \mathrm{~h})}=D_{f i l t e r}+D_{12 \text { hour }} \\
=7.58 \times 10^{-5} \mathrm{SV}+4.17 \times 10^{-4} \mathrm{SV} \\
D_{\text {onsite }(12 \mathrm{~h})}=4.93 \times 10^{-4} \mathrm{~Sv}
\end{gathered}
$$

Total onsite consequences (Annual release):

$$
\begin{aligned}
& D_{\text {onsite (annual) }}=D_{\text {filter }}+D_{\text {annual }} \\
& =7.58 \times 10^{-5} \mathrm{SV}+5.18 \times 10^{-3} \mathrm{~Sv} \\
& D_{\text {onsite (annual) }}=5.26 \times 10^{-3} \mathrm{~Sv}
\end{aligned}
$$

By the same method, onsite radiological consequences are calculated for all release durations using the source term shown in the calculations above and also using the 241-A-101 tank-specific source term ULD (see Table 2). Worksheets detailing the calculations are included in Appendix $C$ with summary results presented in Section 7.0 . 


\section{OFFSITE RADIOLOGICAL CONSEQUENCES}

Consequences from the HEPA Filter Failure $\left(\mathrm{D}_{\mathrm{filter}-i n h a t a t i o n}\right.$ and $D_{\text {filter-ingestion }}$ :

$$
\mathrm{D}_{\mathrm{inh}}(S V)=Q(L) \times \frac{x}{Q^{\prime}}\left(\frac{s}{m^{3}}\right) \times R\left(\frac{m^{3}}{s}\right) \times U L D_{\mathrm{inh}}\left(\frac{S V}{L}\right)
$$

where

$$
\begin{aligned}
& D_{\text {inh }}=\text { dose due to inhalation (SV) } \\
& Q=3.06 \times 10^{-5} \mathrm{~L} \text { (see Table 1) } \\
& X / Q^{\prime}=2.83 \times 10^{-5} \mathrm{~s} / \mathrm{m}^{3} \text { (see Section 2.0) } \\
& R=3.3 \times 10^{-4} \mathrm{~m}^{3} / \mathrm{s} \text { (see Section } 3.0 \text { ) } \\
& U D_{i n h}=2.2 \times 10^{5} \mathrm{SV} / \mathrm{L} \text { (see Table 2) } \\
& \begin{array}{c}
D_{\text {filter-inhalation }}=\left(3.06 \times 10^{-5} \mathrm{~L}\right)\left(2.83 \times 10^{-5} \mathrm{~s} / \mathrm{m}^{3}\right)\left(3.3 \times 10^{-4} \mathrm{~m}^{3} / \mathrm{s}\right) \\
\times\left(2.2 \times 10^{5} \mathrm{~Sv} / \mathrm{L}\right)
\end{array} \\
& D_{\text {filter-inhalation }}=6.29 \times 10^{-8} \mathrm{SV} \\
& D_{\text {ing }}(S V)=Q(L) \times \frac{X}{Q^{\prime}}\left(\frac{s}{m^{3}}\right) \times U L D_{\text {ing }}\left(\frac{s v-m^{3}}{s-L}\right)
\end{aligned}
$$

where

$$
\begin{aligned}
D_{\text {ing }} & =\text { dose due to inhalation (SV) } \\
Q & =3.06 \times 10^{-5} \mathrm{~L}(\text { see Table } 1) \\
X / Q^{\prime} & \left.=2.83 \times 10^{-5} \mathrm{~s} / \mathrm{m}^{3} \text { (see Section } 2.0\right) \\
U L D_{\text {ing }} & =4.1 \mathrm{~Sv}-\mathrm{m}^{3} / \mathrm{s}-\mathrm{L}(\text { see Table } 2) \\
D_{\text {filter-ingestion }} & =\left(3.06 \times 10^{-5} \mathrm{~L}\right)\left(2.83 \times 10^{-5} \mathrm{~s} / \mathrm{m}^{3}\right)\left(4.1 \mathrm{~Sv}-\mathrm{m}^{3} / \mathrm{s}-\mathrm{L}\right) \\
D_{\text {filter-ingestion }} & =3.55 \times 10^{-9} \mathrm{SV}
\end{aligned}
$$


$D_{24 \text { h-ingestion) }):}$

$$
D_{i n h}(S V)=Q(L / s) \times \frac{x}{Q^{1}}\left(\frac{s}{m^{3}}\right) \times R\left(\frac{m^{3}}{s}\right) \times U L D_{i n h}\left(\frac{S V}{L}\right) \times t(s)
$$

where

$$
\begin{aligned}
& D_{\text {inh }}=\text { dose due to inhalation (Sv) } \\
& Q=2.4 \times 10^{-8} \mathrm{~L} / \mathrm{s} \text { (see Table } 5 \text { ) } \\
& X / Q^{\prime}=4.62 \times 10^{-6} \mathrm{~s} / \mathrm{m}^{3} \text { (see Section 2.0) } \\
& R=2.7 \times 10^{-4} \mathrm{~m}^{3} / \mathrm{s} \text { (see Section } 3.0 \text { ) } \\
& \text { ULD }_{i n h}=2.2 \times 10^{5} \mathrm{~Sv} / \mathrm{L} \text { (see Table 2) } \\
& t=86,400 s(24 \mathrm{~h}) \\
& \mathrm{D}_{24 \text { h-inhalation }}=\left(2.4 \times 10^{-8} \mathrm{~L} / \mathrm{s}\right)\left(4.62 \times 10^{-6} \mathrm{~s} / \mathrm{m}^{3}\right)\left(2.7 \times 10^{-4} \mathrm{~m}^{3} / \mathrm{s}\right) \times \\
& \left(2.2 \times 10^{5} \mathrm{SV} / \mathrm{L}\right) \times(86,400 \mathrm{~s}) \\
& \mathrm{D}_{24 \text { h-inhalation }}=5.69 \times 10^{-7} \mathrm{~Sv} \\
& D_{\text {ing }}(S V)=Q(L / s) \times \frac{X}{Q^{1}}\left(\frac{s}{m^{3}}\right) \times U L D_{\text {ing }}\left(\frac{s v-m^{3}}{s-L}\right) \times t(s)
\end{aligned}
$$

where

$$
\begin{aligned}
D_{\text {ing }} & =\text { dose due to inhalation (Sv) } \\
Q & =2.4 \times 10^{-8} \mathrm{~L} / \mathrm{s} \text { (see Table 5) } \\
X / Q^{\prime} & \left.=4.62 \times 10^{-6} \mathrm{~s} / \mathrm{m}^{3} \text { (see Section } 2.0\right) \\
U L D_{\text {ing }} & \left.=4.1 \mathrm{~Sv}-\mathrm{m}^{3} / \mathrm{s}-\mathrm{L} \text { (see Table } 2\right) \\
t & =86,400 \mathrm{~s}(24 \mathrm{~h}) \\
D_{24 \text { h-ingestion }} & =\left(2.4 \times 10^{-8} \mathrm{~L} / \mathrm{s}\right)\left(4.62 \times 10^{-6} \mathrm{~s} / \mathrm{m}^{3}\right)\left(4.1 \mathrm{SV}-\mathrm{m}^{3} / \mathrm{s}-\mathrm{L}\right)(86,400 \mathrm{~s}) \\
D_{24} \text { h-ingestion } & =3.93 \times 10^{-8} \mathrm{SV}
\end{aligned}
$$


( $D_{\left.\text {annual-inhalation and } D_{\text {annual-ingestion }}\right) \text { : }}$

$$
\mathrm{D}_{\mathrm{inh}}(S V)=Q(L / s) \times \frac{X}{Q^{\prime}}\left(\frac{s}{m^{3}}\right) \times R\left(\frac{m^{3}}{s}\right) \times U L D_{\mathrm{inh}}\left(\frac{S V}{L}\right) \times t(s)
$$

where

$$
\begin{aligned}
& D_{\text {inh }}=\text { dose due to inhalation (Sv) } \\
& Q=2.4 \times 10^{-8} \mathrm{~L} / \mathrm{s} \text { (see Table 5) } \\
& X / Q^{\prime}=1.24 \times 10^{-7} \mathrm{~s} / \mathrm{m}^{3} \text { (see Section 2.0) } \\
& R=2.7 \times 10^{-4} \mathrm{~m}^{3} / \mathrm{s} \text { (see Section } 3.0 \text { ) } \\
& U D_{i n h}=2.2 \times 10^{5} \mathrm{~Sv} / \mathrm{L} \text { (see Table 2) } \\
& t=3.1536 \times 10^{7} \mathrm{~s}(8,760 \mathrm{~h}) \text { [additional significant figures } \\
& \text { included to reduce error in final answer] } \\
& D_{\text {annual-inhalation }}=\left(2.4 \times 10^{-8} \mathrm{~L} / \mathrm{s}\right)\left(\frac{1}{5} .24 \times 10^{-7} \mathrm{~s} / \mathrm{m}^{3}\right)\left(2.7 \times 10^{-4} \mathrm{~m}^{3} / \mathrm{s}\right) \times \\
& \left(2.2 \times 10^{5} \mathrm{SV} / \mathrm{L}\right)\left(3.1536 \times 10^{7} \mathrm{~s}\right) \\
& D_{\text {annual-inhalation }}=5.57 \times 10^{-6} \mathrm{SV} \\
& D_{\text {ing }}(S v)=Q(L / s) \times \frac{X}{Q^{\prime}}\left[\frac{s}{m^{3}}\right] \times U L D_{\text {ing }}\left(\frac{s v-m^{3}}{s-L}\right] \times t(s)
\end{aligned}
$$

where

$$
\begin{aligned}
& D_{\text {ing }}=\text { dose due to inhalation (Sv) } \\
& Q=2.4 \times 10^{-8} \mathrm{~L} / \mathrm{s} \text { (see Table 5) } \\
& X / Q^{\prime}=1.24 \times 10^{-7} \mathrm{~s} / \mathrm{m}^{3} \text { (see Section 2.0) } \\
& U_{\text {UL }}=4.1 \mathrm{~Sv}-\mathrm{m}^{3} / \mathrm{s}-\mathrm{L} \text { (see Table 2) } \\
& t=3.1536 \times 10^{7} \mathrm{~s}(8,760 \mathrm{~h}) \text { [additiona] significant figures } \\
& \text { included to reduce error in final answer] } \\
& D_{\text {annual-ingestion }}=\left(2.4 \times 10^{-8} \mathrm{~L} / \mathrm{s}\right)\left(1.24 \times 10^{-7} \mathrm{~s} / \mathrm{m}^{3}\right)\left(4.15 \mathrm{v}-\mathrm{m}^{3} / \mathrm{s}-\mathrm{L}\right) \times \\
& \left(3.1536 \times 10^{7} \mathrm{~s}\right) \\
& \mathrm{D}_{\text {annual-ingestion }}=3.85 \times 10^{-7} \mathrm{SV}
\end{aligned}
$$


Total offsite consequences (24 hour release):

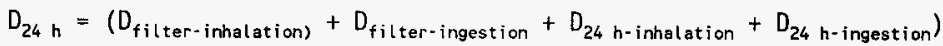

$=6.29 \times 10^{-8} \mathrm{~Sv}+3.55 \times 10^{-9} \mathrm{~Sv}+5.69 \times 10^{-7} \mathrm{~Sv}+3.93 \times 10^{-8} \mathrm{~Sv}$

$$
D_{24 h}=6.48 \times 10^{-7} \mathrm{~Sv}
$$

Total offsite consequences (Annual release):

$$
\begin{gathered}
D_{\text {annual }}=\left(D_{\text {filter-inhalation })}+D_{\text {filter-ingestion }}+D_{\text {annual-inhalation }}+D_{\text {annual-ingestion }}\right) \\
=6.29 \times 10^{-8} \mathrm{~Sv}+3.55 \times 10^{-9} \mathrm{~Sv}+5.57 \times 10^{-6} \mathrm{~Sv}+3.85 \times 10^{-7} \mathrm{~Sv} \\
D_{\text {annual }}=6.02 \times 10^{-6} \mathrm{~Sv}
\end{gathered}
$$

By the same method, offsite radiological consequences are calculated for all release durations using the source term shown in the calculations above and also using the 241-A-101 tank-specific source term ULD (see Table 2). Worksheets detailing the calculations are included in Appendix $C$ with summary results presented in Section 7.0 . 
HNF-SD-WM-CN-107 REV 0

This page intentionally left blank. 


\subsection{TOXICOLOGICAL EXPOSURE CONSEQUENCE ANALYSIS}

The methodology that is used to calculate toxicological exposure consequences is documented in WHC-SD-WM-SARR-011, Rev. 2, Toxic Chemical Considerations for Tank Farm Releases. In this method, the released quantity (or release rate) is multiplied by the appropriate sum-of-fraction (SOF) value from Table 3-8 of WHC-SD-WM-SARR-011. Sum-of-fraction (SOF) values are dependent on the type of release (puff-type or continuous), the waste material released, and the event frequency.

All toxicological exposure calculations in this document are evaluated at a frequency of anticipated (see Section 1.0).

$$
D=Q \cdot S O F
$$

Where

$$
\begin{aligned}
& D=\quad \begin{array}{l}
\text { the variable } D \text { is used to denote the toxicological } \\
\text { exposure consequences and should not be confused with } \\
\text { dose (in the radiological sense). }
\end{array} \\
& Q=\text { the quantity released, in units of } L \text { or } L / s \\
& \text { SOF = } \quad \begin{array}{l}
\text { the appropriate sum-of-fraction value, in units of } L^{-1} \\
\text { or s/L }
\end{array}
\end{aligned}
$$

To demonstrate the way the toxicological consequences are calculated, a sample calculation of the onsite and offsite consequences are presented for the 241-A-101 Exhauster.

\section{ONSITE TOXICOLOGICAL CONSEQUENCES}

Consequences from the HEPA Filter Failure $\left(D_{\text {filter }}\right)$ :

$$
\text { Toxicological Exposure Consequences }=Q \cdot \text { SOF }
$$

Where

$$
\begin{aligned}
& Q= 3.06 \times 10^{-5} \mathrm{~L} \\
& \text { SOF }= 1.2 \times 10^{4} \mathrm{~L}^{-1} \\
& D_{\text {filter }}=\left(3.06 \times 10^{-5} \mathrm{~L}\right)\left(1.2 \times 10^{4} \mathrm{~L}^{-1}\right) \\
& D_{\text {filter }}=3.67 \times 10^{-1}
\end{aligned}
$$


Consequences from the Unfiltered Release $\left(D_{\text {unfittered }}\right)$ : [Note that since the release rate is constant with respect to time (i.e., 1 inear), the evaluated time period of the release (i.e., $12 \mathrm{~h}, 24 \mathrm{~h}$, etc.) is not relevant to the calculation.]

$$
D=Q \cdot S O F
$$

Where

$$
\begin{aligned}
Q & =2.4 \times 10^{-8} \mathrm{~L} / \mathrm{s} \\
\text { SOF } & =4.0 \times 10^{4} \mathrm{~s} / \mathrm{L} \\
& D_{\text {unfiltered }}=\left(2.4 \times 10^{-8} \mathrm{~L} / \mathrm{s}\right)\left(4.0 \times 10^{4} \mathrm{~s} / \mathrm{L}\right) \\
& D_{\text {unfiltered }}=9.60 \times 10^{-4}
\end{aligned}
$$

Total onsite consequences:

$$
\begin{gathered}
D_{\text {onsite }}=D_{\text {filter }}+D_{\text {unfiltered }} \\
=3.67 \times 10^{-1}+9.60 \times 10^{-4} \\
D_{\text {onsite }}=3.68 \times 10^{-1}
\end{gathered}
$$

These consequences are identical for any of the continuous release durations. Since a separate or tank-specific toxicological source term was not developed in WHC-SD-WM-SAD-036, toxicological exposure calculations using an alternate source term are not performed in this document. Summary results of toxicological consequence calculations are presented in Section 7.0 .

\section{OFFSITE TOXICOLOGICAL CONSEQUENCES}

Consequences from the HEPA Filter Failure $\left(D_{\text {filter }}\right)$ :

$$
\mathrm{D}=\mathrm{Q} \cdot \mathrm{SOF}
$$

Where

$$
\begin{aligned}
Q= & 3.06 \times 10^{-5} \mathrm{~L} \\
\text { SOF }= & 3.8 \times 10^{-1} \mathrm{~L}^{-1} \\
& D_{\text {filter }}=\left(3.06 \times 10^{-5} \mathrm{~L}\right)\left(3.8 \times 10^{-1} \mathrm{~L}^{-9}\right) \\
& D_{\text {filter }}=1.16 \times 10^{-5}
\end{aligned}
$$




\section{HNF-SD-WM-CN-107 REV 0}

Consequences from the Unfiltered Release $\left(D_{\text {unfiltered }}\right):$ [Note that since the release rate is constant with respect to time (i.e., linear), the evaluated time period of the release (i.e., $12 \mathrm{~h}, 24 \mathrm{~h}$, etc.) is not relevant to the calculation.]

$$
\mathrm{D}=\mathrm{Q} \cdot \mathrm{SOF}
$$

Where

$$
\begin{aligned}
Q & =2.4 \times 10^{-8} \mathrm{~L} / \mathrm{s} \\
\text { SOF } & =9.4 \times 10^{1} \mathrm{~s} / \mathrm{L} \\
D_{\text {unfiltered }} & =\left(2.4 \times 10^{-8} \mathrm{~L} / \mathrm{s}\right)\left(9.4 \times 10^{1} \mathrm{~s} / \mathrm{L}\right) \\
& D_{\text {unfiltered }}=2.26 \times 10^{-6}
\end{aligned}
$$

Total offsite consequences:

$$
\begin{gathered}
D_{\text {offsite }}=D_{\text {filter }}+D_{\text {unfiltered }} \\
=1.16 \times 10^{-5}+2.26 \times 10^{-6} \\
D_{\text {offsite }}=1.39 \times 10^{-5}
\end{gathered}
$$

These consequences are identical for any of the continuous release durations. Since a separate or tank-specific toxicological source term was not developed in WHC-SD-WM-SAD-036, toxicological exposure calculations using an alternate source term are not performed in this document. Summary results of toxicological exposure calculations are presented in Section 7.0. 
HNF-SD-WM-CN-107 REV 0

This page intentionally left blank. 
HNF-SD-WM-CN-107 REV 0

\subsection{ANALYSIS RESULTS}

\subsection{RADIOLOGICAL CONSEQUENCES}

The onsite and offsite radiological consequences of this scenario are summarized in Tables 6 and 7 , respectively, for comparison with the risk guidelines.

\section{Bounding Source Term ULD}

The onsite radiological consequences calculated using the bounding source term ULD (see Table 2) show that for release durations of $12 \mathrm{hrs}$, 1 week, 1 month, 3 months, and 6 months, the consequences are below the risk guidelines. As such, no controls are necessary to protect required for these systems. However, the onsite radiological consequences calculated for the $1 \mathrm{yr}$ (annual) unfiltered release following the HEPA failure are slightly above the risk guidelines and would therefore require the development of a safety SSC or controls to protect the onsite receptor from a year-long release from this ventilation system.

It is also interesting to note that even if the dose contribution from the failed HEPAs is not included in the total onsite radiological dose for the year-long release, the consequences still exceed the risk guidelines. This demonstrates the maximum radiological dose consequences that could be attributed to an unfiltered release (e.g., due to seal failure, defective or deteriorated HEPA filters, or improper installation of the HEPA filters).

The offsite radiological consequences calculated using the bounding source term ULD (see Table 2) show that for all release durations the consequences are below the risk guidelines. As such, no safety SSCs or controls are necessary to protect the offsite receptor.

In addition to the discussion provided, there is still the requirement for the control cited in Section 1 to protect the key assumption regarding the HEPA filter loading amount. Table 10 in Section 8 summarizes this control.

\section{Tank-Specific Source Term ULD}

The onsite and offsite radiological consequences calculated using the tank-specific source term ULD (see Table 2) show that for all release durations the consequences are below the risk guidelines. As such, no safety SSCS or controls are necessary to protect either the onsite or offsite receptors.

In addition to the discussion provided, there is still the requirement for the control cited in Section 1 to protect the key assumption regarding the HEPA filter loading amount. Table 10 in Section 8 summarizes this control.

\subsection{TOXICOLOGICAL CONSEQUENCES}

Similarly, the onsite and offsite toxicological consequences of this scenario are summarized in Tables 8 and 9 , respectively. The onsite and offsite toxicological consequences for a 11 release durations are below the risk guidelines. 
Table 6. Summary of Onsite Radiological Consequences Assuming No Controls.

\begin{tabular}{|c|c|c|c|c|c|c|c|c|}
\hline \multirow{3}{*}{$\begin{array}{l}\text { FACILITY/VENT } \\
\text { SYSTEM }\end{array}$} & \multicolumn{7}{|c|}{ ONSITE RADIOLOGICAL CONSEQUENCES } & \multirow{3}{*}{$\begin{array}{l}\text { Risk } \\
\text { Guidel ine } \\
\text { (Sv) }\end{array}$} \\
\hline & $\begin{array}{c}\text { Dose from } \\
\text { Filter } \\
\text { failure } \\
\text { (Sv) }\end{array}$ & $\begin{array}{c}\text { Total Dose from } \\
12 \text { h Unf i ltered } \\
\text { Release } \\
\text { (Sv) } \\
\text { (includes } \\
\text { anount from } \\
\text { Column A) }\end{array}$ & $\begin{array}{c}\text { Total Dose from } \\
1 \text { wk Unfiltered } \\
\text { Release } \\
\text { (Sv) } \\
\text { (includes } \\
\text { amount from } \\
\text { Colum A) }\end{array}$ & $\begin{array}{l}\text { Total Dose } \\
\text { from i Month } \\
\text { Unf i t tered } \\
\text { Release } \\
\text { (Sv) } \\
\text { (includes } \\
\text { amount from } \\
\text { Column A) }\end{array}$ & $\begin{array}{c}\text { Total Dose } \\
\text { from } 3 \text { Month } \\
\text { Unfiltered } \\
\text { Release } \\
\text { (SV) } \\
\text { (includes } \\
\text { amount from } \\
\text { Colum A) }\end{array}$ & $\begin{array}{l}\text { Total Dose } \\
\text { from } 6 \text { Month } \\
\text { Unfil tered } \\
\text { Rel ease } \\
\text { (Sv) } \\
\text { (includes } \\
\text { amount from } \\
\text { Column A) }\end{array}$ & $\begin{array}{l}\text { Total Dose from } \\
1 \text { yr Unfiltered } \\
\text { Release } \\
\text { (Sv) } \\
\text { (includes } \\
\text { anount from } \\
\text { Column A) }\end{array}$ & \\
\hline & A & B & c & D & E & $\mathbf{F}$ & G & \\
\hline $\begin{array}{l}\text { 241-A-101 Exhauster } \\
\text { (bounding SI) }\end{array}$ & $7.58 E-05$ & $4.93 \mathrm{E}-04$ & $2.13 \mathrm{E}-03$ & $1.23 \mathrm{E}-03$ & $2.32 E-03$ & $3.49 \mathrm{E}-03$ & $5.26 E-03$ & $5.0 \mathrm{E}-03$ \\
\hline $\begin{array}{l}241-A-101 \text { Exhauster } \\
\text { (SAD-036 ST) }\end{array}$ & $2.54 E-05$ & $1.65 E-04$ & 7.14 E- 04 & 4.14 E-04 & $7.80 E-04$ & $1.17 \mathrm{E}-03$ & $1.77 E-03$ & 5.0 E -03 \\
\hline
\end{tabular}

ST $=$ Source Term

을 $r \mathrm{em}=\mathrm{Sv} \times 100$

g

Table 7. Summary of Offsite Radiological Consequences Assuming No Controls.

\begin{tabular}{|c|c|c|c|c|c|c|c|c|}
\hline \multirow{3}{*}{$\begin{array}{l}\text { FACILITY/VENT } \\
\text { SYSTEM }\end{array}$} & \multicolumn{7}{|c|}{ ONSITE RADIOLOGICAL CONSEQUENCES } & \multirow{3}{*}{$\begin{array}{l}\text { Risk } \\
\text { Guidel ine } \\
\text { (Sv) }\end{array}$} \\
\hline & $\begin{array}{c}\text { Dose from } \\
\text { Filter } \\
\text { Failure } \\
\text { (SV) }\end{array}$ & $\begin{array}{l}\text { Total Dose from } \\
24 \text { h Unfiltered } \\
\text { Release } \\
\text { (SV) } \\
\text { (includes } \\
\text { amount from } \\
\text { Colum A) }\end{array}$ & $\begin{array}{l}\text { Total Dose from } \\
1 \text { wk Unfiltered } \\
\text { Release } \\
\text { (SV) } \\
\text { (includes } \\
\text { amount from } \\
\text { Column A) }\end{array}$ & $\begin{array}{l}\text { Total Dose } \\
\text { from I Month } \\
\text { Unfil tered } \\
\text { Release } \\
\text { (SV) } \\
\text { (includes } \\
\text { amount from } \\
\text { Colum A) }\end{array}$ & $\begin{array}{c}\text { Total Dose } \\
\text { from } 3 \text { Month } \\
\text { Unfiltered } \\
\text { Release } \\
\text { (Sv) } \\
\text { (includes } \\
\text { amount from } \\
\text { Colum A) }\end{array}$ & $\begin{array}{l}\text { Total Dose } \\
\text { from } 6 \text { Month } \\
\text { Unfil tered } \\
\text { Release } \\
\text { (Sv) } \\
\text { (includes } \\
\text { amount from } \\
\text { Column A) }\end{array}$ & $\begin{array}{c}\text { Total Dose from } \\
1 \text { yr Unfiltered } \\
\text { Release } \\
\text { (Sv) } \\
\text { (includes } \\
\text { amount from } \\
\text { Column A) }\end{array}$ & \\
\hline & A & B & $\mathrm{c}$ & 0 & $\mathbf{E}$ & $\mathrm{F}$ & G & \\
\hline $\begin{array}{l}241-A-101 \text { Exhauster } \\
\text { (bounding ST) }\end{array}$ & $6.65 E-08$ & $6.75 \mathrm{E}-07$ & $1,36 E-06$ & $8.23 E-07$ & $1.22 \mathrm{E}-06$ & 1.58 E-06 & 2.05 E-06 & $1.0 \mathrm{E}-03$ \\
\hline $\begin{array}{l}\text { 241-A-101 Exhauster } \\
\text { (SAD-036 ST) }\end{array}$ & $2.11 E-08$ & 2.12 E-07 & $1.37 E-07$ & $2.26 \mathrm{E}-07$ & 3.34 E-07 & $4.31 E-07$ & $5.57 \mathrm{E}-07$ & $1.0 \mathrm{E}-03$ \\
\hline
\end{tabular}

ST $=$ Source $\mathrm{Term}$

rem $=\mathrm{SV} \times 100$ 
Table 8. Summary of Onsite Toxicological Consequences Assuming No Controls.

\begin{tabular}{|c|c|c|c|c|}
\hline \multirow{3}{*}{ FACILITY/VENT SYSTEM } & \multicolumn{3}{|c|}{ ONSITE TOXICOLOGICAL CONSEQUENCES } & \multirow{3}{*}{$\begin{array}{c}\text { RISK } \\
\text { GUIDELINE }\end{array}$} \\
\hline & $\begin{array}{c}\text { Dose from } \\
\text { Filter } \\
\text { Failure }\end{array}$ & $\begin{array}{c}\text { Dose from } \\
\text { Unfiltered } \\
\text { Release }\end{array}$ & $\begin{array}{c}\text { Total } \\
\text { Onsite Dose }\end{array}$ & \\
\hline & A & B & $A+B$ & \\
\hline 241-A-101 Exhauster & $3.67 \mathrm{E}-0 \mathrm{l}$ & $9.60 E-04$ & $3.68 \mathrm{E}-01$ & 1 \\
\hline
\end{tabular}

Table 9. Summary of Offsite Toxicological Consequences Assuming No Controls.

\begin{tabular}{|c|c|c|c|c|}
\hline \multirow{3}{*}{ FACILITY/VENT SYSTEM } & \multicolumn{3}{|c|}{ OFFSITE TOXICOLOGICAL CONSEQUENCES } & \multirow{3}{*}{$\begin{array}{c}\text { RISK } \\
\text { GUIDELINE }\end{array}$} \\
\hline & $\begin{array}{c}\text { Dose from } \\
\text { Filter } \\
\text { Failure }\end{array}$ & $\begin{array}{c}\text { Dose from } \\
\text { Unfiltered } \\
\text { Release }\end{array}$ & $\begin{array}{l}\text { Total } \\
\text { Offsite } \\
\text { Dose }\end{array}$ & \\
\hline & A & B & $A+B$ & \\
\hline 241-A-101 Exhauster & $1.16 \mathrm{E}-05$ & $2.26 \varepsilon-06$ & $1.39 \mathrm{E}-05$ & 1 \\
\hline
\end{tabular}


HNF-SD-WM-CN-107 REV 0

This page intentionally left blank. 


\subsection{CONCLUSIONS}

The onsite radiological consequences, when calculated using the bounding source term ULD, exceed the risk guideline for the 1 yr (annual) release duration of this accident. Therefore, to protect the onsite receptor from a year-long release from this ventilation system, the development of a safety SSC or control(s) are required to satisfy the safety function of limiting an unfiltered release of ventilation exhaust to the atmosphere to period of 6 months or less. The onsite radiological dose consequences for a 6 month release are significantly below the risk guideline value.

The onsite radiological dose consequences from all other release durations, calculated using the bounding source term ULD, are below the risk guidelines.

The offsite radiological dose consequences calculated using the bounding source term ULD and the onsite and offsite radiological dose consequences calculated using the tank-specific source term ULD are all shown to be below the risk guidelines.

For toxicological exposure consequences, all calculated values (onsite and offsite receptors) are below the risk guidelines.

Table 10 lists a summary of the Technical Safety Requirements selected to mitigate the risk of HEPA filter failure due to a fire (or overtemperature) for the 241-A-101 exhauster. For the TSR 1isted, the safety function is described and additional comments are provided as appropriate. This control is credited in the $\mathrm{BIO}$ and further details regarding its development are provided in HNF-SD-WM-TSR-006, Tank Waste Remediation System Technical Safety Requirements.

Table 10. Summary of Technical Safety Requirements.

\begin{tabular}{|l|l|l|}
\hline \multicolumn{1}{|c|}{ Control } & \multicolumn{1}{|c|}{ Safety function } & \multicolumn{1}{c|}{ Comments } \\
\hline $\begin{array}{l}\text { HEPA Filter Control } \\
\text { Program } \\
\text { with the following key } \\
\text { elements: }\end{array}$ & $\begin{array}{l}\text { Reduce consequences } \\
\text { from a possible HEPA } \\
\text { filter failure by } \\
\text { limiting the inventory } \\
\text { available }\end{array}$ & $\begin{array}{l}\text { Applies to all HEPA } \\
\text { filters and prefilters } \\
\text { in the ventilation } \\
\text { system }\end{array}$ \\
$\begin{array}{l}\text { Periodic radiation } \\
\text { survey to monitor } \\
\text { HEPA filter loading }\end{array}$ & \\
$\begin{array}{l}\text { HEPA filter } \\
\text { replacement per } \\
\text { change-out criteria, } \\
\text { i.e., 2 mSv/h } \\
\text { (200 mrem/h) }\end{array}$ & & \\
\hline
\end{tabular}

HEPA = high-efficiency particulate air (filter). 
HNF-SD-WM-CN-107 REV 0

This page intentionally left blank.

36 of 60 


\section{HNF-SD-WM-CN-107 REV 0}

\subsection{REFERENCES}

\section{Documents}

DOE-HDBK-3010-94, DOE Handbook Airborne Release Fractions/Rates and Restorable Fraction for Nonreactor Nuclear Facilities, U.S. Department of Energy, Richl and, Washington.

HNF-SD-WM-TSR-006, Tank Waste Remediation System Technical Safety Requirements, Rev. J, Fluor Daniel Hanford, Richland, Washington.

RH0-RE-SA-216, 1987, Characterization of Airborne Radionuclide Particulates in Ventilated Liquid Waste Tanks, Rockwell Hanford Operations, Richl and, Washington.

WHC-SD-WM-CN-033, MICROSHIELD Dose Rate Calculations for HEPA Filters and Prefilters, Rev. 0, Westinghouse Hanford Company, Richland, Washington.

WHC-SD-WM-CN-056, 1996, Fire in a Contaminated Area, Rev. 2, Westinghouse Hanford Company, Richland, Washington.

WHC-SD-WM-CN-062, 1996, HEPA Filter Failure by Fire or Heater Overtemperature and Subsequent Unfiltered Release, Rev. 2, Westinghouse Hanford Company, Richl and, Washington.

WHC-SD-WM-SAD-036, Safety Assessment for Salt Well Jet Pumping Operations in Tank 241-A-101: Hanford Site, Richland, Washington, Rev. 0 , Westinghouse Hanford Company, Richland, Washington.

WHC-SD-WM-SARR-011, Toxicological Chemical Considerations for Tank Farm Releases, Rev. 2, Westinghouse Hanford Company, Richland, Washington.

WHC-SD-WM-SARR-016, Tank Waste Compositions and Atmospheric Dispersion Coefficients for Use in Safety Analys is Consequence Assessments, Rev. 2, Westinghouse Hanford Company, Richland, Washington.

WHC-SD-WM-SARR-037, Development of Radiologica7 Concentration and Unit Liter Doses for Tank Waste Remediation System Final Safety Analysis Report Radiological Consequence Calculations, Rev. 0, Westinghouse Hanford Company, Richland, Washington.

WHC-CM-4-46, Safety Analys is Manual, Section 4.0, Rev. 1, November 15, 1991, Westinghouse Hanford Company, Richland, Washington.

\section{Drawings}

Hanford design drawing $H-14-100737$, sheet 10 , revision 0 , dated $8 / 29 / 96$, and titled 500 CFM PORTABLE EXHAUSTER DETAILS. 
HNF-SD-WM-CN-107 REV 0

This page intentionally left blank. 
HNF-SD-WM-CN-107 REV 0

APPENDIX A

DEVELOPMENT AND DISCUSSION OF HEPA FILTER RELEASE AMOUNTS 
HNF-SD-WM-CN-107 REV 0

This page intentionally left blank. 
This appendix discusses the method used to calculate the amount of material on the filters in various tank farm facilities. To do this, WHC-SD-WM-CN-033 modeled $3.7 \times 10^{10} \mathrm{~Bq}(\mathrm{Ci})$ of gamma emitters in different filter configurations and calculated the contact doses. Depending on the source material, the gamma emitters are different. For example, single-shell solids are dominated by ${ }^{90} \mathrm{Sr},{ }^{90} \mathrm{Y},{ }^{137} \mathrm{Cs}$ and ${ }^{154} \mathrm{Eu}$ for gamma emitters while double-shell 1 iquids are dominated by ${ }^{137} \mathrm{Cs}$ (the other gamma emitters have much smaller concentrations). The spreadsheet tables give the relative amounts for each of the cases that were analyzed.

Different filter geometries were modeled. These include high efficiency particulate air filters and prefilters. After putting in the geometry and the loading, a dose rate $(\mathrm{mSv} / \mathrm{hr})$ was calculated.

High efficiency particulate air filters and prefilters have pre-specified operating limits. These were used, along with the calculated dose rate to form a ratio of the operating limit to the calculated dose 1 imit. This gives the fraction of the assumed waste volume that could be loaded on the filter and give the operating limit. The amount of material released from the single bank of filters was calculated using one of the following schemes.

- The system is a standard active ventilation system with a prefilter, a first stage and second stage high efficiency particulate air filter. An additional amount, equal to another prefilter loading, was used to account for material that will come out of the ventilation duct work. That is, two prefilter volumes plus two high efficiency particulate air filter volumes will be used.

- The system is passively ventilated. The system is basically one high efficiency particulate filter sitting on a riser. There is not a prefilter and there is no ventilation ducting to speak of. That is one high efficiency particulate air filter will be used.

- The system has two de-entrainers, a first stage and second stage high efficiency particulate air filter. To account for the loading in the de-entrainers and the material that will come out of the ventilation duct work, an additional volume equivalent to total of five times the loading for one high efficiency particulate filter will be used.

- The system consists of a prefilter, a low efficiency filter (treated as another prefilter), a first stage and second stage high efficiency particulate air filter. In addition, a volume equal to the prefilter will be used to account for material from the ventilation ducting. That is, a total of three prefilter volumes and two high efficiency particulate volumes will be used.

The spreadsheet pages also identify how many filter banks are running at the same time. A total amount of material released from the filters is found by multiplying by the appropriate release fraction. For a filter fire, the release fraction is $1 / 10,000$ of the volume is released. The volumes released are then to be used to calculate radiological and toxicological doses (see Sections 5.0 and 6.0 , respectively). 


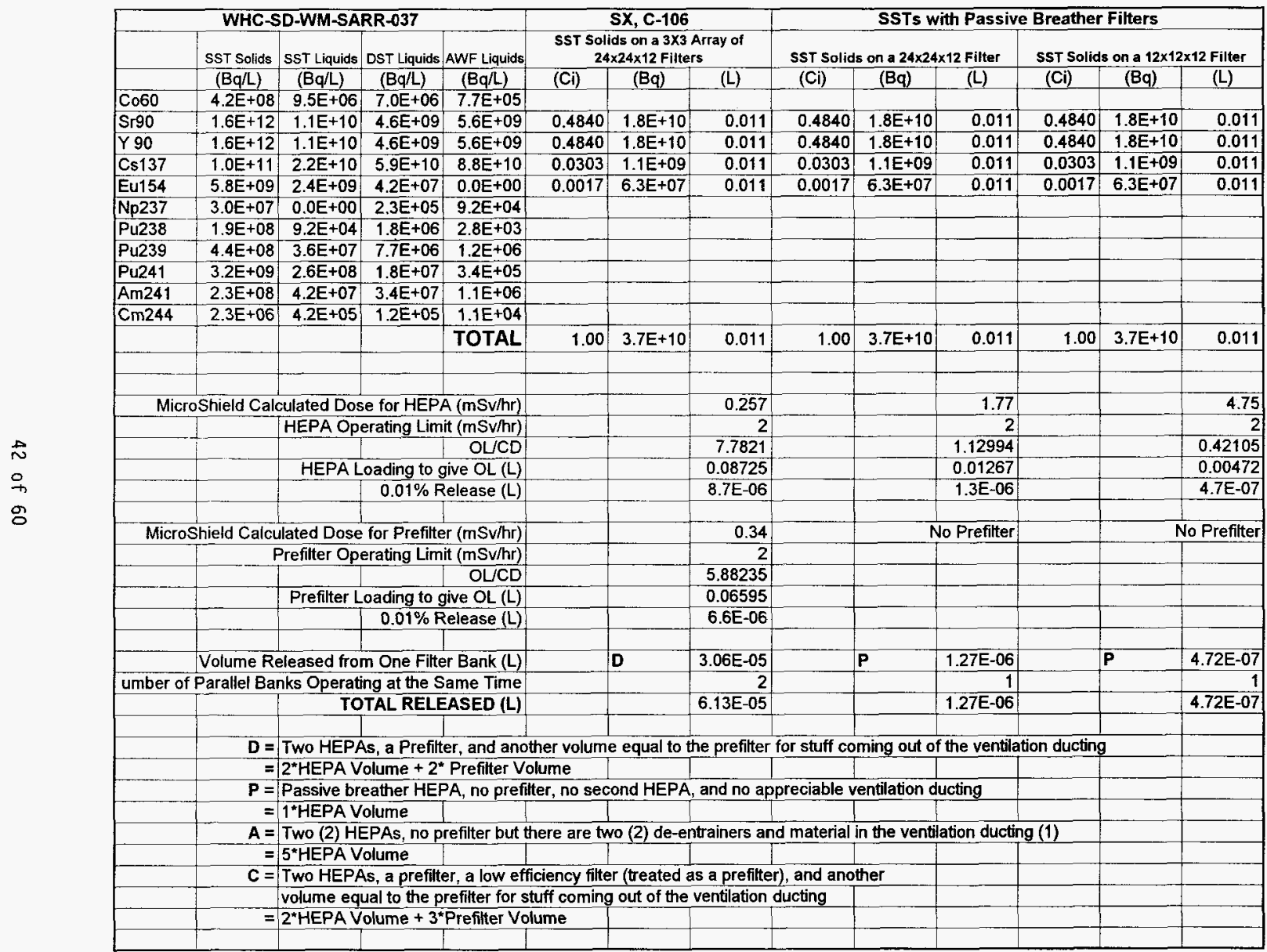




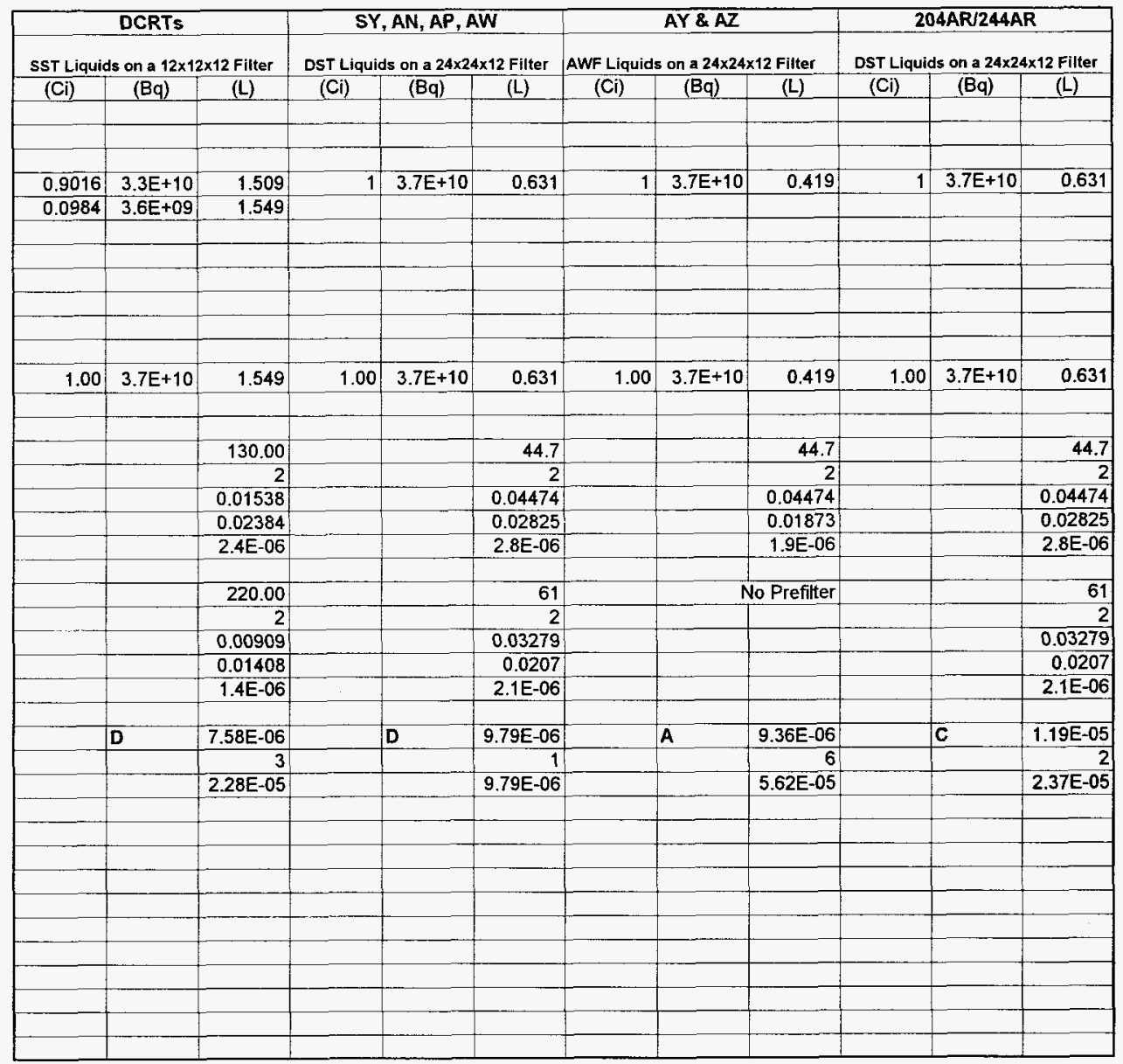


HNF-SD-WM-CN-107 REV 0

This page intentionally left blank. 
HNF-SD-WM-CN-107 REV 0

\section{APPENDIX B}

BACKGROUND INFORMATION 
HNF-SD-WM-CN-107 REV 0

This page intentionally left blank. 
Author: Michael A (Mike) Lane at HANFORDO4C

Date: $3 / 4 / 97 \quad 10: 31$ AM

Priority: Normal

CC: David T Vladimiroff at KEH1O

CC: William H (Bi11) Meader at WHC225

CC: Gary W Gault at HANFORDO7E

CC: Ryan D Smith at HANFORDO7E

TO: Grant W Ryan at ־HANFORD02D

Subject: Re: Ventilation System Info. Requested

Mike,

To be able to complete the analysis that was discussed this morning, this is some of the information that I need on the SWP exhausters:

With respect to the A-101 SWP exhauster (if you want to know specifics on the 1,000 scfm units, you need to talk to Eric Veith, Owen Nelson or Jim Kriskovich):

1. Maximum design flowrate (cfm) 500

2. Number, size, and configuration of filters (parallel or series) 2, 24" $X 24^{\prime \prime} \times 5-7 / 8^{\prime \prime}$, series stack

3. Inside dimensions of inlet and outlet exhaust piping.12" inlet, 6"

4. Will all the filters be replaced at the same time? You need to ask Krisko or Owen Nelson this.

5. Will the efficiency testing be performed by the same crew that installs the filters? You need to ask Krisko or Owen Nelson this.

6. Drawing numbers (H-2s) of ventilation system or supply a copy of the drawings. H-14-020160, H-14-100737, H-14-100763, H-14-100764, $\mathrm{H}-14-100765, \mathrm{H}-14-100766$ (also ECN 627434)

7. Filter media (e.g., fiberglass?) I believe it is some kind of fiberglass, but you should check this with Krisko or Owen Nelson.

8. Positioning of the exhauster in relation to the tank being exhausted. see ECNs 627398, 633119 and 635642

We can discuss the other design features of the exhauster later, after we know if we have to look at them as possible controls.

Once I get this information I can submit it back to someone on your side who can sign off on the assumptions so there will be no questions later why I used the information that I did. I suggest that you have Krisko do it.

Thanks.

Grant 
HNF-SD-WM-CN-107 REV 0

This page intentionally left blank. 
HNF-SD-WM-CN-107 REV 0

APPENDIX C

DETAILED CONSEQUENCE ANALYSIS RESULTS

49 of 60 
HNF-SD-WM-CN-107 REV 0

This page intentionally left blank. 


\begin{tabular}{|c|c|c|c|c|c|c|c|c|c|}
\hline \multirow[b]{2}{*}{ Facility/Vent System } & \multirow[b]{2}{*}{$\begin{array}{c}\text { Amount of } \\
\text { Waste } \\
\text { Released } \\
\text { from HEPA } \\
\text { Filter (L) } \\
\end{array}$} & \multirow[b]{2}{*}{$\begin{array}{l} \\
\text { Particulate } \\
\text { Release } \\
\text { Rate (Us) }\end{array}$} & \multicolumn{7}{|c|}{ ONSITE RADIOLOGICAL CONSEQUENCES (ASSUMING NO CONTROLS) } \\
\hline & & & \begin{tabular}{|c|} 
Dose \\
from \\
Filter \\
Failure \\
[D, filter] \\
(Sv)
\end{tabular} & $\begin{array}{c}\text { Dose from } \\
12 \mathrm{~h} \\
\text { Unfiltered } \\
\text { Release } \\
{[D, 12 \text { hour }]} \\
\text { (Sv) }\end{array}$ & $\begin{array}{c}\text { Dose from } \\
1 \text { wk } \\
\text { Unfiltered } \\
\text { Release } \\
\text { [D,1 wk] } \\
\text { (Sv) }\end{array}$ & $\begin{array}{c}\text { Dose from } \\
1 \text { month } \\
\text { Unfiltered } \\
\text { Release } \\
{[D, 1 \text { month }]} \\
(\mathrm{Sv})\end{array}$ & $\begin{array}{c}\text { Dose from } \\
3 \text { month } \\
\text { Unfiltered } \\
\text { Release } \\
\text { [D,3 month] } \\
\text { (Sv) }\end{array}$ & $\begin{array}{c}\text { Dose from } \\
6 \text { month } \\
\text { Unfiltered } \\
\text { Release } \\
{[D, 6 \text { month }]} \\
\text { (Sv) }\end{array}$ & $\begin{array}{c}\text { Dose from } \\
\text { Annual } \\
\text { Unfiltered } \\
\text { Release } \\
{[D, 1 \mathrm{yr}]} \\
\text { (Sv) }\end{array}$ \\
\hline 241-A-101 Exhauster (bounding ST) & $3.06 \mathrm{E}-05$ & $2.4 \mathrm{E}-08$ & $7.58 \mathrm{E}-05$ & $4.17 \mathrm{E}-04$ & $2.05 \mathrm{E}-03$ & $1.16 \mathrm{E}-03$ & $2.25 \mathrm{E}-03$ & $3.41 \mathrm{E}-03$ & $5.18 \mathrm{E}-03$ \\
\hline 241-A-101 Exhauster (SAD-036 ST) & 3.06 E-05 & $2.4 \mathrm{E}-08$ & $2.54 \mathrm{E}-05$ & $1.40 \mathrm{E}-04$ & $6.89 \mathrm{E}-04$ & $3.89 \mathrm{E}-04$ & $7.55 \mathrm{E}-04$ & $1.15 \mathrm{E}-03$ & $1.74 \mathrm{E}-03$ \\
\hline & & & & & & & & & \\
\hline \multirow[t]{3}{*}{ ST = source term } & \multicolumn{3}{|c|}{ Dispersion Coefficients } & & \multicolumn{2}{|c|}{ Release Period (s) } & & & \\
\hline & & Onsite & offsite & & 43,200 & $(12 \mathrm{hr})$ & & & \\
\hline & & $(\mathrm{s} / \mathrm{m} 3)$ & $(\mathrm{s} / \mathrm{m} 3)$ & & 86,400 & $(24 \mathrm{hr})$ & & & \\
\hline & acute & $3.41 \mathrm{E}-02$ & $2.83 \mathrm{E}-05$ & & 606,600 & $(1 \mathrm{wk})$ & & & \\
\hline & 12 hour & $5.54 \mathrm{E}-03$ & NA & & $2,628,000$ & (1 month) & & & \\
\hline & 24 hour & N/A & $4.62 \mathrm{E}-06$ & & $7,884,000$ & (3 months) & & & \\
\hline & 1 week & $1.94 \mathrm{E}-03$ & $1.40 \mathrm{E}-06$ & & $15,768,000$ & (6 months) & & & \\
\hline & 1 month & $1.08 \mathrm{E}-03$ & $5.69 \mathrm{E}-07$ & & $31,536,000$ & $(1 \mathrm{yr})$ & & & \\
\hline & 3 months & 6.99E-04 & 2.90E-07 & & & & & & \\
\hline & 6 months & 5.31E-04 & $1.90 \mathrm{E}-07$ & & & ULDs & & & \\
\hline & annual & 4.03E-04 & $1.24 \mathrm{E}-07$ & & & Inhalation & \begin{tabular}{|l|l} 
Ingestion \\
\end{tabular} & & \\
\hline & & & & & & (Sv/L) & $(\mathrm{Sv} \mathrm{m} 3) /(\mathrm{s} \mathrm{L})$ & & \\
\hline & \multicolumn{2}{|c|}{ Occupancy Factor } & & \multicolumn{2}{|c|}{ SST Solids (bounding) } & $2.2 \mathrm{E}+05$ & 4.1 & & \\
\hline & & \begin{tabular}{|r|}
0.286 \\
\end{tabular} & & \multicolumn{2}{|c|}{ SST Solids (SAD-036) } & $7.4 \mathrm{E}+04$ & of & & \\
\hline & & & & & & & & & \\
\hline & \multicolumn{3}{|c|}{ Standard Man Breathing Rate } & & & & & & \\
\hline & & $(\mathrm{m} 3 / \mathrm{s})$ & & & & & & & \\
\hline & & 2.70E-04 & & & & & & & \\
\hline & & $3.30 \mathrm{E}-04$ & & & & & & & \\
\hline
\end{tabular}




\begin{tabular}{|c|c|c|c|c|c|c|}
\hline \multirow[b]{2}{*}{ Facility/Vent System } & \multicolumn{6}{|c|}{ ONSITE RADIOLOGICAL CONSEQUENCES (ASSUMING NO CONTROLS) } \\
\hline & $\begin{array}{c}\text { Total Onsite } \\
\text { Dose (12 h } \\
\text { Release) } \\
{[\mathrm{D}, \text { onsite }} \\
(12 \mathrm{~h})](\mathrm{Sv})\end{array}$ & $\begin{array}{c}\text { Total } \\
\text { Onsite } \\
\text { Dose (1 wk } \\
\text { Release) } \\
{[D, \text { onsite }} \\
(1 \text { wk)] (Sv) }\end{array}$ & $\begin{array}{c}\text { Total Onsite } \\
\text { Dose (1 month } \\
\text { Release) } \\
{[D, \text { onsite }} \\
\text { (1 month)] (Sv) }\end{array}$ & $\begin{array}{c}\text { Total Onsite } \\
\text { Dose (3 month } \\
\text { Release) } \\
\text { [D, onsite } \\
\text { (3 month)] (Sv) }\end{array}$ & $\begin{array}{c}\text { Total Onsite } \\
\text { Dose (6 month } \\
\text { Release) } \\
\text { [D, onsite } \\
(6 \text { month)] (Sv) }\end{array}$ & $\begin{array}{c}\text { Total } \\
\text { Onsite } \\
\text { Dose (1 yr } \\
\text { Release) } \\
{[\mathrm{D} \text {, onsite }} \\
(1 \mathrm{yr})] \text { (Sv) }\end{array}$ \\
\hline 241-A-101 Exhauster (bounding ST) & $4.93 \mathrm{E}-04$ & $2.13 E-03$ & $1.23 \mathrm{E}-03$ & $2.32 \mathrm{E}-03$ & $3.49 \mathrm{E}-03$ & $5.26 \mathrm{E}-03$ \\
\hline 241-A-101 Exhauster (SAD-036 ST) & $1.66 \mathrm{E}-04$ & $7.14 \mathrm{E}-04$ & $4.14 \mathrm{E}-04$ & 7.80 E-04 & $1.17 \mathrm{E}-03$ & $1.77 \mathrm{E}-03$ \\
\hline \multicolumn{7}{|l|}{$\mathrm{ST}=$ source term } \\
\hline \multirow{2}{*}{\multicolumn{7}{|c|}{$\mathrm{ST}=$ source term }} \\
\hline & & & & & & \\
\hline & & & & & & \\
\hline & & & & & & \\
\hline & & & & & & \\
\hline & & & & & & \\
\hline & & & & & & \\
\hline & & & & & & \\
\hline & & & & & & \\
\hline & & & & & & \\
\hline & & & & & & \\
\hline & & & & & & \\
\hline & & & & & & \\
\hline & & & & & & \\
\hline & & & & & & \\
\hline & $\therefore$ & & & & & \\
\hline & & & & & & \\
\hline & & & & & & \\
\hline & & & & & & \\
\hline
\end{tabular}




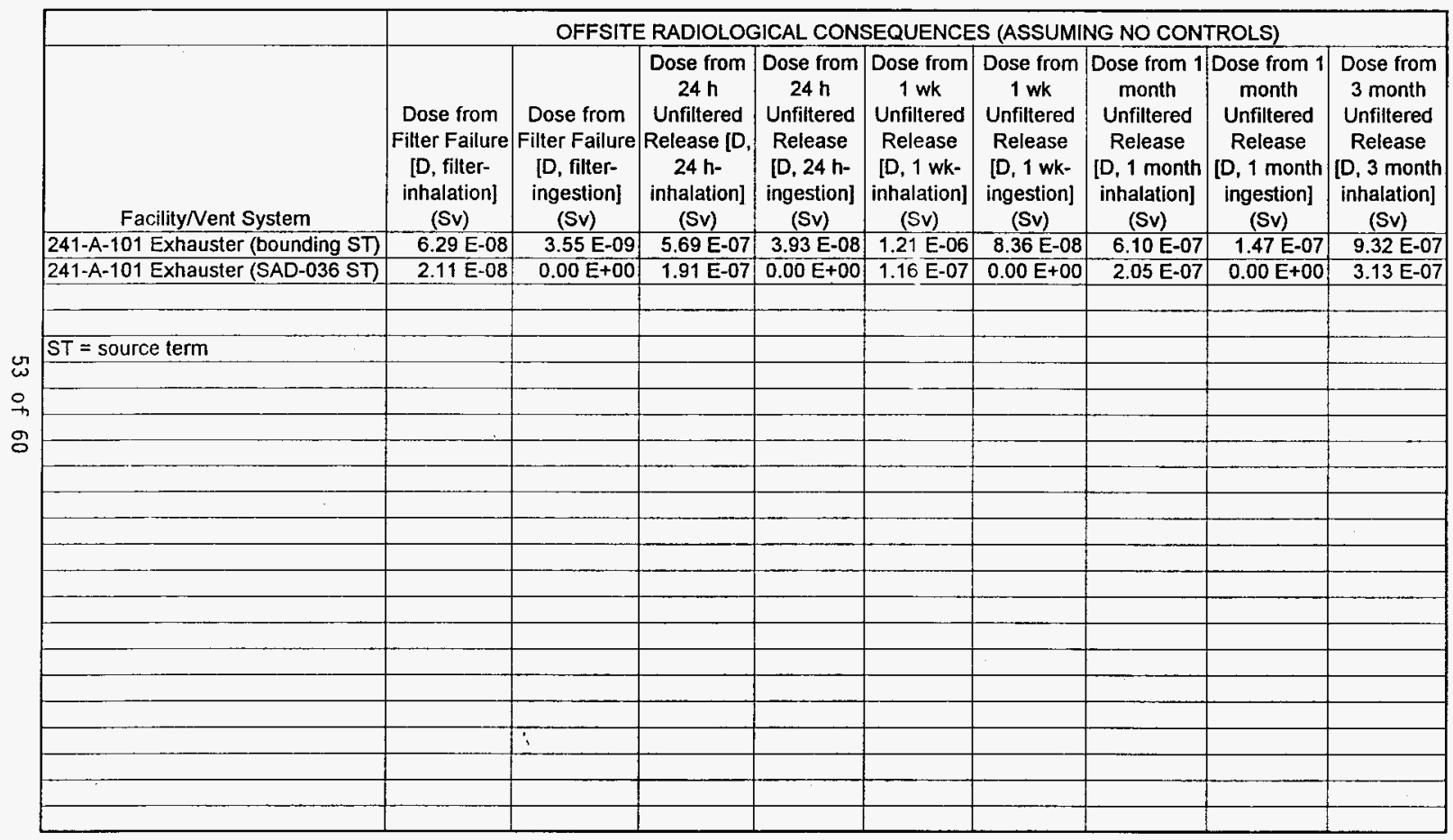




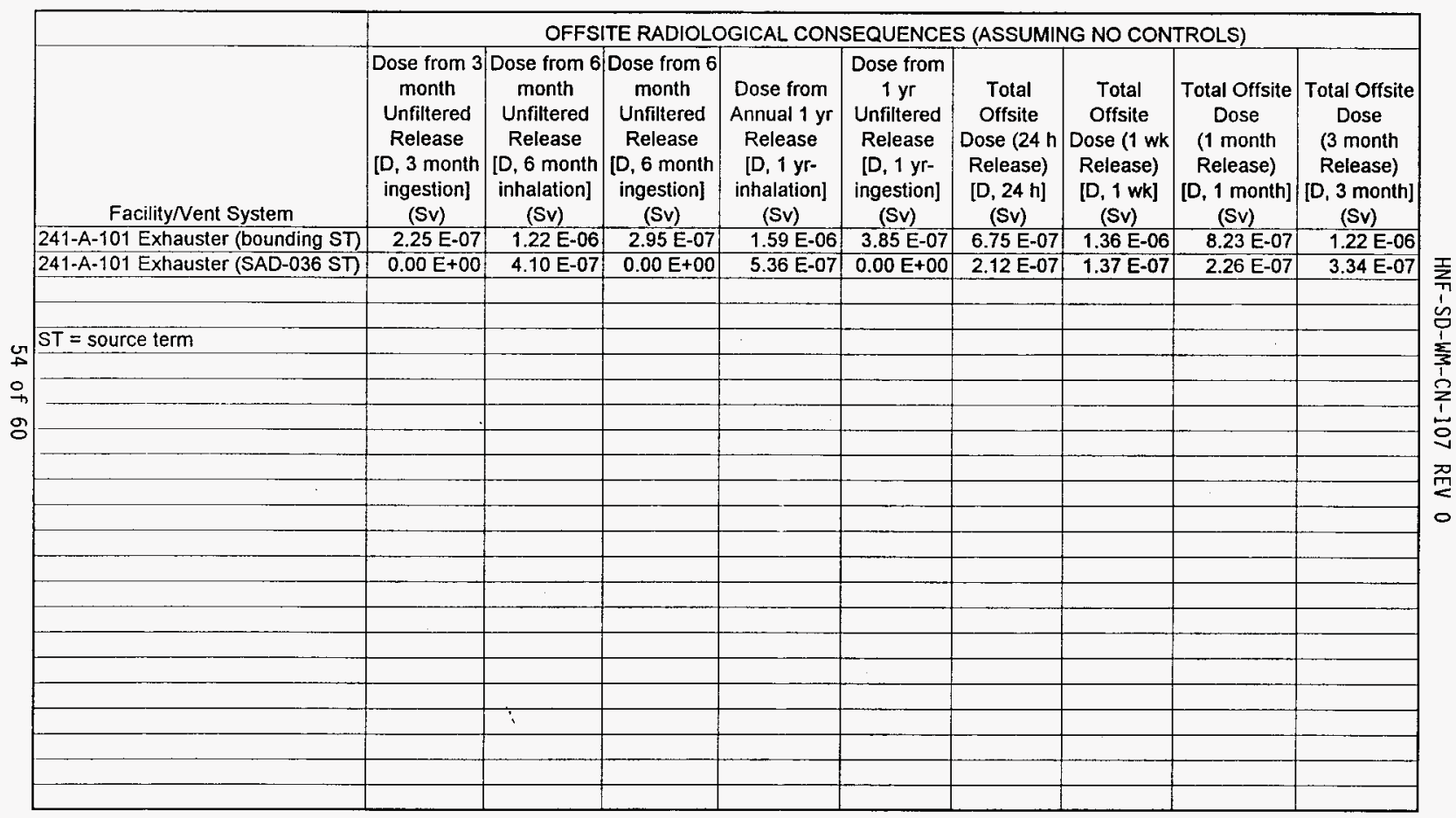


A101.XLS

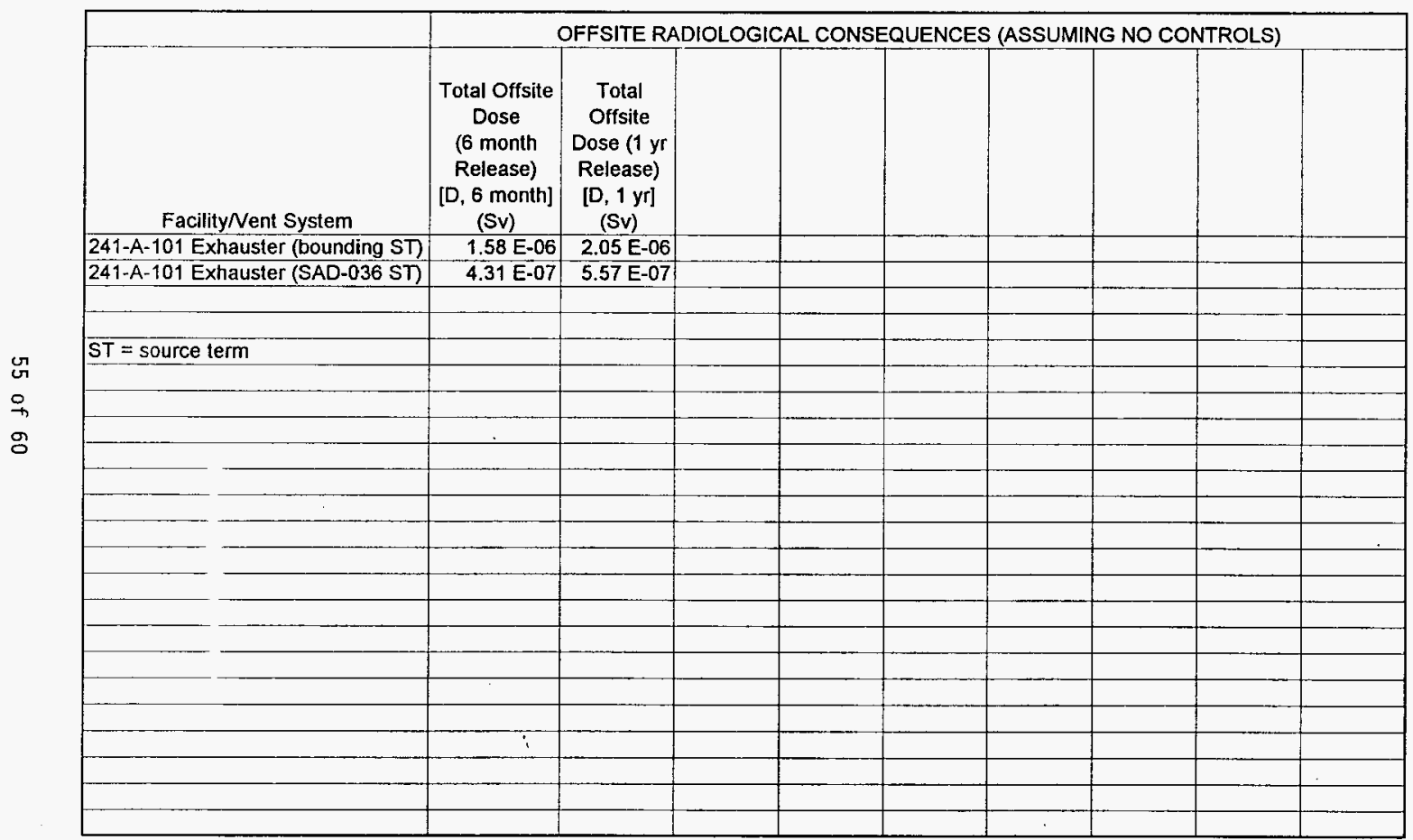


HNF-SD-WM-CN-107 REV 0

This page intentionally left blank. 
HNF-SD-WM-CN-107 REV 0

APPENDIX D

PEER REVIEW AND HEDOP REVIEW CHECKLISTS 
HNF-SD-WM-CN-107 REV 0

This page intentionally left blank.

58 of 60 
HNF-SD-WM-CN-107 REV 0

\section{CHECKLIST FOR PEER REVIEW}

Document Reviewed: HNF-SD-WM-CN-107, Rev. 0, Ventilation System Consequence Calculations to Support Salt Well Pumping Single-Shell

Tank 241-A-101.

Scope of Review:

Yes No NA

[X] [ ] [ ] *

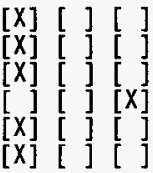

[X] [ ] [ ]

[X] [ ] [ ]

[X] [ ] [ ]

[][]$[x]$

[X] [ ] [ ]

$\left.\begin{array}{llll}{[X]} & {[} & {[} & {[}\end{array}\right]$

$[X][][]$

[X] [ ] [ ]

[ ] $[\mathrm{X}]$ *

Previous reviews complete and cover analysis, up to scope of this review, with no gaps.

Problem completely defined.

Accident scenarios developed in a clear and logical manner. Necessary assumptions explicitly stated and supported.

Computer codes and data files documented.

Data used in calculations explicitly stated in document.

Data checked for consistency with original source information as applicable.

Mathematical derivations checked including dimensional consistency of results.

Models appropriate and used within range of validity or use outside range of established validity justified.

Hand calculations checked for errors. Spreadsheet results should be treated exactly the same as hand calculations. Software input correct and consistent with document reviewed. Software output consistent with input and with results reported in document reviewed.

Limits/criteria/guidelines applied to analysis results are appropriate and referenced. Limits/criteria/guidelines checked against references.

Safety margins consistent with good engineering practices.

Conclusions consistent with analytical results and applicable limits.

Results and conclusions address all points required in the problem statement.

Format consistent with appropriate NRC Regulatory Guide or other standards

Review calculations, comments, and/or notes are attached.

\section{[X] [ ] [ ] Document approved.}

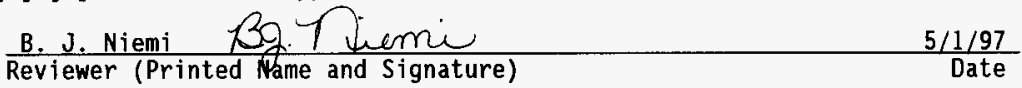

* Any calculations, comments, or notes generated as part of this review should be signed, dated and attached to this checklist. Such material should be labeled and recorded in such a manner as to be intelligible to a technically qualified third party.

$$
\begin{aligned}
& \text { NOTE: HEDOP REVIEW NOT REQUIRED SINUS DATA USEO IN } \\
& \text { THE DEVELOPMENT OF THE CALC. NOTE WAS } \\
& \text { EXTRACTED FROM BOTH SARR-OII AND SARR-OIL. } \\
& \text { THESE DOCUMENTS HAVE BEON FORMERY HEDOP } \\
& \text { REVIEWEO ANO APPROVED. }
\end{aligned}
$$


HNF-SD-WM-CN-107 REV 0

This page intentionally left blank. 


\section{DISTRIBUTION SHEET}

\begin{tabular}{|c|c|c|c|c|c|}
\hline \multirow{2}{*}{$\begin{array}{l}\text { To } \\
\text { Distribution }\end{array}$} & \multirow{2}{*}{\multicolumn{3}{|c|}{$\begin{array}{l}\text { From } \\
\text { TWRS Safety Analysis }\end{array}$}} & \multicolumn{2}{|l|}{ Page 1 of 1} \\
\hline & & & & \multicolumn{2}{|c|}{ Date May 2, 1997} \\
\hline \multicolumn{4}{|l|}{ Project Title Work Order } & \multicolumn{2}{|c|}{ EDT No. 621228} \\
\hline \multicolumn{4}{|c|}{$\begin{array}{l}\text { HNF-SD-WM-CN-107, Ventilation System Consequence Calculations to } \\
\text { Support Salt Well Pumping Single-She11 Tank 241-A-101 }\end{array}$} & \multicolumn{2}{|c|}{ ECN No. N/A } \\
\hline Name & MSIN & $\begin{array}{c}\text { Text } \\
\text { With All } \\
\text { Attach. }\end{array}$ & Text Only & $\begin{array}{l}\text { Attach./ } \\
\text { Appendix } \\
\text { Only }\end{array}$ & $\begin{array}{l}\text { EDT/ECN } \\
\text { Only }\end{array}$ \\
\hline $\begin{array}{l}\text { G. W. Gault } \\
\text { T. C. Geer } \\
\text { G. L. Jones } \\
\text { J. R. Kriskovich } \\
\text { W. H. Meader } \\
\text { B. J. Niemi } \\
\text { G. W. Ryan (3) } \\
\text { R. D. Smith } \\
\text { A. R. Tedeschi } \\
\text { D. T. V1adimiroff } \\
\text { TWRS S\&L Files (2) } \\
\text { Central Files (original + 1) }\end{array}$ & $\begin{array}{r}R 1-44 \\
R 1-43 \\
R 1-44 \\
R 1-56 \\
S 8-05 \\
R 1-44 \\
R 1-44 \\
R 1-49 \\
R 1-56 \\
S 8-05 \\
A 2-26 \\
A 3-88 \text { A3-34 } \\
\end{array}$ & $\begin{array}{l}x \\
x \\
x \\
x \\
x \\
x \\
x \\
x \\
x \\
x \\
x \\
x\end{array}$ & & & \\
\hline
\end{tabular}

